\title{
Summertime contributions of isoprene, monoterpenes, and sesquiterpene oxidation to the formation of secondary organic aerosol in the troposphere over Mt. Tai, Central East China during MTX2006
}

P. Q. Fu ${ }^{1}$, K. Kawamura ${ }^{1}$, P. Pochanart ${ }^{2}$, H. Tanimoto ${ }^{3}$, Y. Kanaya ${ }^{2}$, and Z. F. Wang ${ }^{4}$

${ }^{1}$ Institute of Low Temperature Science, Hokkaido University, Sapporo, Japan

${ }^{2}$ Frontier Research Center for Global Change, Japan Agency for Marine-Earth Science and Technology, Yokohama, Japan

${ }^{3}$ National Institute for Environmental Studies, Tsukuba, Japan
Formation of secondary organic aerosol over Mt. Tai during MTX2006

P. Q. Fu et al.

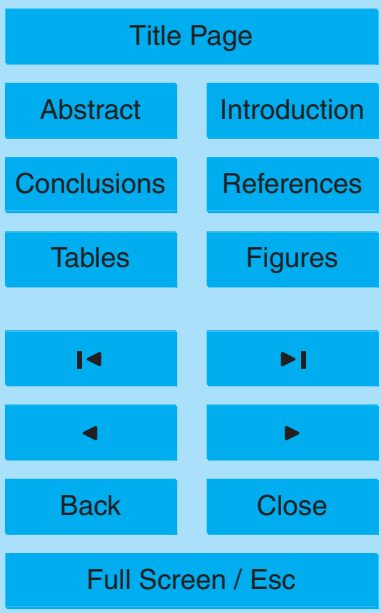

Printer-friendly Version

Interactive Discussion 
${ }^{4}$ LAPC/NZC, Institute of Atmospheric Physics, Chinese Academy of Sciences, Beijing, China

Received: 19 June 2009 - Accepted: 2 August 2009 - Published: 10 August 2009

Correspondence to: P. Q. Fu (pqfu@ pop.lowtem.hokudai.ac.jp)

Published by Copernicus Publications on behalf of the European Geosciences Union.
ACPD

9, 16941-16972, 2009

\section{Formation of secondary organic aerosol over Mt. Tai during MTX2006}

P. Q. Fu et al.

Title Page

Abstract Introduction

Conclusions References

Tables Figures

14

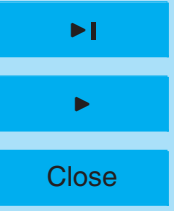

Back

Full Screen / Esc

Printer-friendly Version

Interactive Discussion 


\section{Abstract}

To better understand the contribution of biogenic volatile organic compounds to the formation of secondary organic aerosol (SOA) in high mountain regions, ambient aerosols were collected at the summit of Mt. Tai (1534 m, a.s.I.), Central East China (CEC) dur5 ing the Mount Tai eXperiment 2006 campaign (MTX2006) in early summer. Biogenic SOA tracers of isoprene, monoterpenes, and $\beta$-caryophyllene oxidation products were measured using gas chromatography/mass spectrometry. All the biogenic SOA tracers showed no clear diurnal variations, suggesting that they are formed during longrange atmospheric transport. Although isoprene- and monoterpene-derived SOA tracers did not correlate with levoglucosan (a biomass burning tracer), $\beta$-caryophyllinic acid showed a good correlation with levoglucosan, indicating that biomass burning may be a source for this compound. Total concentrations of isoprene oxidation products are much higher than those of monoterpene and $\beta$-caryophyllene oxidation products. The ratio of isoprene to monoterpene oxidation products $\left(R_{\text {iso/mono }}\right)$ was found to co-vary 15 with ozone and $\mathrm{NO}_{\mathrm{x}}$ during the summer campaign. The average $R_{\text {iso/mono }}$ value was 6.94 at daytime and 10.0 at nighttime. These values are among the highest in the aerosols studied in different regions, which may be due to the large isoprene fluxes, high $\mathrm{O}_{3}$ and $\mathrm{NO}_{\mathrm{x}}$ levels and relatively high $\mathrm{OH}$ concentrations in CEC. Using a tracerbased method, we estimated the average concentrations of secondary organic carbon 20 (SOC) derived from isoprene, monoterpenes, and $\beta$-caryophyllene to be $1.76 \mu \mathrm{gC} \mathrm{m}^{-3}$ at daytime and $1.85 \mu \mathrm{gC} \mathrm{m}^{-3}$ at nighttime. These values correspond to $11.2 \%$ and $11.0 \%$ of the total OC concentrations, in which isoprene-derived SOC are $7.4 \%$ and $8.0 \%$ at day- and night-time, respectively. This study suggests that isoprene is a more significant precursor for biogenic SOA than monoterpenes and $\beta$-caryophyllene in high

\section{Formation of secondary organic aerosol over Mt. Tai during MTX2006}

P. Q. Fu et al.

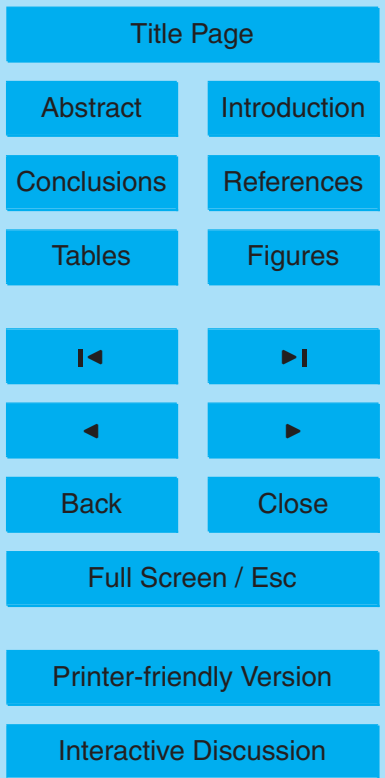




\section{Introduction}

Secondary organic aerosol (SOA) is an important component in the Earth's atmosphere. It may provide surfaces for heterogeneous reactions in the atmosphere, and can impact on the atmospheric radiation budget directly by scattering sunlight and in5 directly by acting as cloud condensation nuclei (Kanakidou et al., 2005; Pöschl, 2005). The photooxidation of biogenic volatile organic compounds (BVOCs) that are emitted from vegetation to the atmosphere is an important source of SOA. On a global scale, emissions of BVOCs are suggested to be one order of magnitude larger than those of anthropogenic VOCs (Seinfeld and Pandis, 2006). Monoterpenes and sesquiterpenes

10 are believed to be the largest biogenic sources of SOA mass, with global model estimates ranging from 12-70 $\mathrm{Tg} \mathrm{yr}^{-1}$ (Kanakidou et al., 2005). Claeys et al. (2004a) first identified two diastereoisomeric 2-methyltetrols in Amazonian rain forest aerosols as photooxidation products of isoprene. They estimated its SOA production to be $2 \mathrm{Tg} \mathrm{yr}^{-1}$ globally. Isoprene is the most abundant non-methane hydrocarbon (c.a. $600 \mathrm{Tg} \mathrm{yr}^{-1}$ ) 15 emitted into the Earth's atmosphere (Guenther et al., 2006). Even its small SOA yield could enhance the predicted SOA formation seriously.

In forested areas, biogenic emissions may govern the air chemistry and SOA formation in summer when intense sunlight and high ambient temperatures are common. High loading of natural aerosols over boreal forests was reported in northern Europe 20 (Tunved et al., 2006). In the past decade, the identification of SOA tracers of isoprene, monoterpenes, and sesquiterpene oxidation products has been conducted in chamber experiments (Yu et al., 1999; Edney et al., 2005; Böge et al., 2006; Jaoui et al., 2007; Ma et al., 2007; Szmigielski et al., 2007a, b) and ambient aerosols from urban (Xia and Hopke, 2006; Hu et al., 2008), forested or mountain areas (Kavouras et al., 1998, 1999; Claeys et al., 2004a; Ion et al., 2005; Kourtchev et al., 2005, 2008b, 2009; Cahill et al., 2006; Kleindienst et al., 2007a; Wang et al., 2008), as well as the Arctic region (Fu et al., 2009). However up to date, information with regard to the BVOCs oxidation products in high altitudes is still limited. High mountains may provide a unique situation for

\section{Formation of secondary organic aerosol over Mt. Tai during MTX2006}

P. Q. Fu et al.

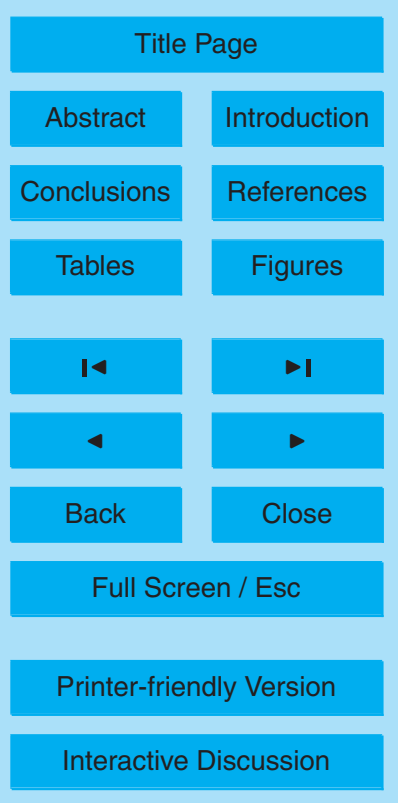


atmospheric chemistry because they sometimes exist in the free troposphere (FT) due to the downward movement of the planetary boundary layer (PBL) at nighttime. Recently, Heald et al. (2005) reported a large, sustained source of SOA in the FT from the oxidation of long-lived volatile organic compounds. A global model study showed that 5 at higher altitudes, the isoprene oxidation products have much greater concentrations than other biogenic SOA precursors (Henze and Seinfeld, 2006).

The objective of this research was to characterize the chemical compositions and abundance of SOA tracers from isoprene, $\alpha-/ \beta$-pinene and $\beta$-caryophyllene oxidation, and to evaluate their contributions to organic carbon in the tropospheric 10 aerosols over Mount Tai, Central East China (CEC). During the Mount Tai eXperiment 2006 (MTX2006) field campaign, simultaneous studies of ozone, nitrogen oxides $\left(\mathrm{NO}_{\mathrm{x}}=\mathrm{NO}+\mathrm{NO}_{2}\right)$ and hydroxyl radical $(\mathrm{OH})$ were conducted, which help us to better understand the atmospheric behaviors of biogenic SOA tracers in the troposphere over high mountains.

\section{Experimental section}

\subsection{Aerosol sampling}

Mt. Tai $\left(36.25^{\circ} \mathrm{N}\right.$ and $117.10^{\circ} \mathrm{E}, 1534 \mathrm{~m}$ above sea level) is located in Shandong Province, Central East China (CEC, $30^{\circ} \mathrm{N}-40^{\circ} \mathrm{N}$ and $110^{\circ} \mathrm{E}-130^{\circ} \mathrm{E}$ ), where the elevations in most of the flat region are less than $200 \mathrm{~m}$. It lies in deciduous forest zone, in which about $80 \%$ are covered with vegetation. Almost 1000 species are known to grow in the mountain area. However, vegetations at the mountaintop are limited to bushes and the ground surfaces are mostly covered with rocks. As part of MTX2006 campaign, daytime/nighttime and three-hour aerosol sampling were performed from 28 May to 28 June 2006 at the balcony of the 2 nd floor of observatory ( $\sim 10 \mathrm{~m}$, above ground level) on the top of Mt. Tai using pre-combusted $\left(450^{\circ} \mathrm{C}\right.$ for $\left.6 \mathrm{~h}\right)$ quartz fiber filters and high-volume air sampler.

\section{Formation of secondary organic aerosol over Mt. Tai during MTX2006}

P. Q. Fu et al.

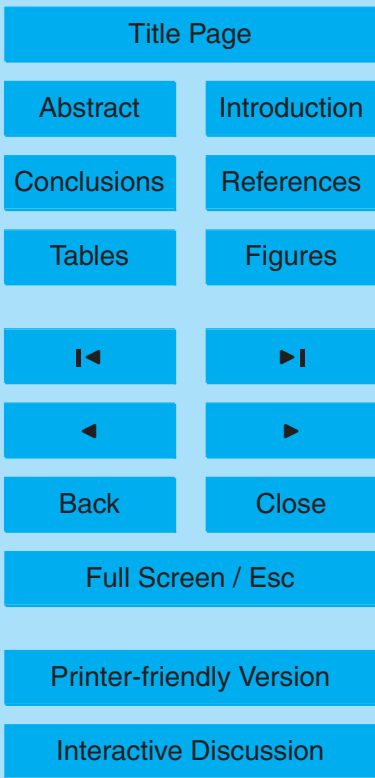




\subsection{Extraction, derivatization, and GC/MS determination}

Details of the sample extraction and derivatization are presented elsewhere (Fu et al., 2008). Briefly, filter aliquots were extracted with dichloromethane/methanol $(2: 1, \mathrm{v} / \mathrm{v})$, followed by concentration, and derivatization with $50 \mu \mathrm{IN}, \mathrm{O}-\mathrm{bis}-$ 5 (trimethylsilyl)trifluoroacetamide (BSTFA) in the presence of $1 \%$ trimethylsilyl chloride and $10 \mu \mathrm{l}$ of pyridine prior to GC/MS injection. GC/MS analyses of samples were performed on a Hewlett-Packard model 6890 GC coupled to Hewlett-Packard model 5973 mass-selective detector (MSD). The GC was equipped with a split/splitless injection and a DB-5MS fused silica capillary column $(30 \mathrm{~m} \times 0.25 \mathrm{~mm}$ i.d., $0.25 \mu \mathrm{m}$ film thick10 ness) with the $\mathrm{GC}$ oven temperature programmed from $50^{\circ} \mathrm{C}(2 \mathrm{~min})$ to $120^{\circ} \mathrm{C}$ at $15^{\circ} \mathrm{C} \mathrm{min}{ }^{-1}$ and then to $300^{\circ} \mathrm{C}$ at $5^{\circ} \mathrm{C} \mathrm{min}^{-1}$ with final isothermal hold at $300^{\circ} \mathrm{C}$ for $16 \mathrm{~min}$. The mass spectrometer was operated on the electron impact (EI) mode at $70 \mathrm{eV}$ and scanned from 50 to $650 \mathrm{Da}$. Data were acquired and processed with the Chemstation software.

15 Individual compounds were identified by comparison of mass spectra with those of authentic standards or literature data (Claeys et al., 2004b; Jaoui et al., 2005; Hu et al., 2008; Kourtchev et al., 2008b; Wang et al., 2008). For the quantification of cis-pinonic, norpinic and pinic acids, their GC/MS response factors were determined using authentic standards. 3-Methyl-1,2,3-butanetricarboxylic, 3-hydroxyglutaric, and

$20 \beta$-caryophyllinic acids were estimated using the response factors of pimelic, malic and pinic acids, respectively. 2-Methylglyceric acid, $\mathrm{C}_{5}$-alkene triols and 2-methyltetrols were quantified using the response factor of meso-erythritol. Field blank filters were treated as the real samples for quality assurance. Target compounds were not detected in the blanks. Recoveries for the authentic standards or surrogates that were spiked 25 into pre-combusted quartz filters $(n=3)$ were $94 \pm 2.6 \%$ for meso-erythritol, $69 \pm 6.3 \%$ for malic acid, $64 \pm 5.9 \%$ for cis-pinonic acid, $93 \pm 2.3 \%$ for trans-norpinic acid, and $79 \pm 2.3 \%$ for pinic acid. The data reported here were not corrected for the recoveries. Relative standard deviation of the concentrations based on duplicate analysis was

\section{Formation of secondary organic aerosol over Mt. Tai during MTX2006 \\ P. Q. Fu et al.}

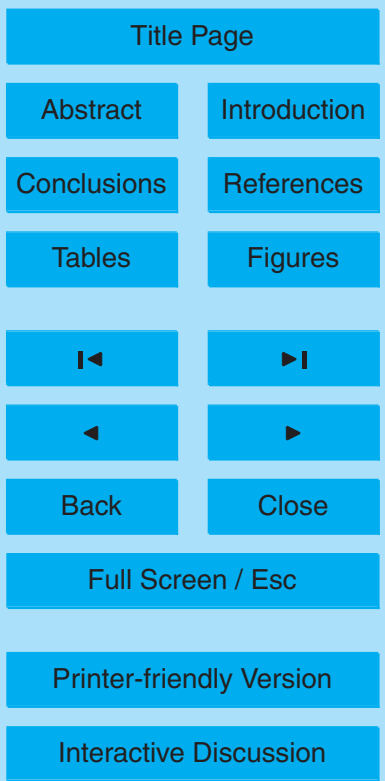


generally $<10 \%$.

\section{$2.3 \mathrm{O}_{3}$ and $\mathrm{NO}_{\mathrm{x}}$ measurement}

$\mathrm{O}_{3}$ was measured by an instrument based on ultraviolet absorption (Thermo, model $49 \mathrm{C}) . \mathrm{NO}_{\mathrm{x}}\left(\mathrm{NO}+\mathrm{NO}_{2}\right)$ were detected by a customized instrument based on a 5 commercially available instrument (Thermo, model 42CTL). The sensitivity to NO was determined against a premixed gas of $\mathrm{NO} / \mathrm{N}_{2}$ (2.004 ppmv, Taiyo Nippon Sanso Corporation). The detection limit of the instrument is specified to be $0.1 \mathrm{ppbv}$ for $\mathrm{NO}$ and $0.2 \mathrm{ppbv}$ for $\mathrm{NO}_{2}$. Detailed information about the measurements of $\mathrm{O}_{3}$ and $\mathrm{NO}_{\mathrm{x}}$ are presented elsewhere (Kanaya et al., 2009; Pochanart et al., 2009).

\section{Results and discussion}

\subsection{Isoprene, $\alpha-/ \beta$-pinene, and $\beta$-caryophyllene oxidation products}

Six compounds were identified as isoprene SOA tracers in the tropospheric aerosols over Mt. Tai, including 2-methylglyceric acid, three $\mathrm{C}_{5}$-alkene triols, and two 2methyltetrols (2-methylthreitol and 2-methylerythritol) (Table 1). Concentration ranges 15 of 2-methyltetrols were $20.2-333 \mathrm{ng} \mathrm{m}^{-3}$ (average $128 \mathrm{ng} \mathrm{m}^{-3}$ ) at daytime and $4.71-$ $550 \mathrm{ng} \mathrm{m}^{-3}\left(148 \mathrm{ng} \mathrm{m}^{-3}\right)$ at nighttime with 2-methylerythritol being about 2.1-fold more abundant than 2-methylthreitol (Table 1). The ratio is similar to those observed in other studies (Claeys et al., 2004a; Ion et al., 2005; Cahill et al., 2006). The levels of 2-methyltetrols reported here are comparable to those reported in Mt. Changbai, 20 Northeast China (22-282 $\mathrm{ng} \mathrm{m}^{-3}$ ) (Wang et al., 2008), and are slightly higher than those reported in the Amazon (Claeys et al., 2004a), Hungary (Ion et al., 2005), Finland (Kourtchev et al., 2008a), Germany (Kourtchev et al., 2008b), and United States (Cahill et al., 2006; Clements and Seinfeld, 2007; Ding et al., 2008).

$\mathrm{C}_{5}$-alkene triols, which are recently reported as photooxidation products of isoprene 25 (Wang et al., 2005), were detected in all samples with an average concentration of

\section{Formation of secondary organic aerosol over Mt. Tai during MTX2006}

P. Q. Fu et al.

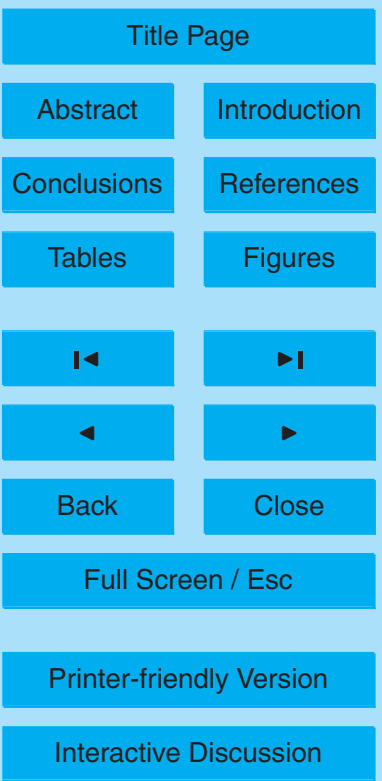


$32.7 \pm 20.8 \mathrm{ng} \mathrm{m}^{-3}$ at daytime and $32.0 \pm 26.9 \mathrm{ng} \mathrm{m}^{-3}$ at nighttime, which are comparable to those $\left(\sim 50 \mathrm{ng} \mathrm{m}^{-3}\right)$ reported in subtropical Hong Kong (Hu et al., 2008), but are higher than those reported in other studies from midlatitudes, e.g. a Californian pine forest, USA (3.47 $\mathrm{ng} \mathrm{m}^{-3}$ ) (Cahill et al., 2006) and Jülich, Germany (1.6-4.9 $\mathrm{ng} \mathrm{m}^{-3}$ ) 5 (Kourtchev et al., 2008b), and 2-3 orders of magnitude higher than those reported in the Arctic (Fu et al., 2009). The concentration ranges of 2-methylglyceric acid, which is possibly formed by further oxidation of methacrolein and methacrylic acid from isoprene (Claeys et al., 2004b; Surratt et al., 2006), were $12.7-110 \mathrm{ng} \mathrm{m}^{-3}\left(51.5 \mathrm{ng} \mathrm{m}^{-3}\right)$ at daytime and $4.28-110 \mathrm{ng} \mathrm{m}^{-3}\left(45.7 \mathrm{ng} \mathrm{m}^{-3}\right)$ at nighttime in the Mt. Tai aerosols.

Pinonic, norpinic, and pinic acids were detected as monoterpene oxidation products. These acids are produced by photooxidation of $\alpha$-/ $\beta$-pinene via reactions with $\mathrm{O}_{3}$ and $\mathrm{OH}$ radicals (Hoffmann et al., 1997; Yu et al., 1999; Glasius et al., 2000; linuma et al., 2004). They have been observed in smog chamber experiments (Jang and Kamens, 1998; Yu et al., 1999; Glasius et al., 2000) and reported in the ambient aerosols (Kavouras et al., 1999; Ding et al., 2008; Kourtchev et al., 2008b; Fu et al., 2009). Concentrations of pinonic, norpinic, and pinic acids in this study ranged from $0.21-21.8 \mathrm{ng} \mathrm{m}^{-3}, 0.07-1.99 \mathrm{ng} \mathrm{m}^{-3}$ and $0.36-6.27 \mathrm{ng} \mathrm{m}^{-3}$, respectively (Table 1). Even though the vapor pressure of pinonic acid is about 2 orders of magnitude higher than pinic acid, the concentrations of pinonic acid in the Mt. Tai aerosols were about 202 times more abundant than pinic acid. Similar patterns have been reported in other studies (Kavouras et al., 1999; Kavouras and Stephanou, 2002; Cahill et al., 2006; Bhat and Fraser, 2007; Yan et al., 2008). However, higher concentrations of pinic acid than pinonic acid have been reported in the aerosols from a coniferous forest in Germany (Plewka et al., 2006) and Research Triangle Park (RTP), USA (Kleindienst et al., 25 2007a).

Two novel compounds were recently identified in aerosols as 3-hydroxyglutaric acid (3-HG) (Claeys et al., 2007) and 3-methyl-1,2,3-butanetricarboxylic acid (MBTCA) (Szmigielski et al., 2007a). Both 3-HG and MBTCA are generated in smog chamber experiments of $\alpha$-pinene with an irradiation of $\mathrm{UV}$ in the presence of $\mathrm{NO}_{\mathrm{x}}$. Concentration

\section{Formation of secondary organic aerosol over Mt. Tai during MTX2006}

P. Q. Fu et al.

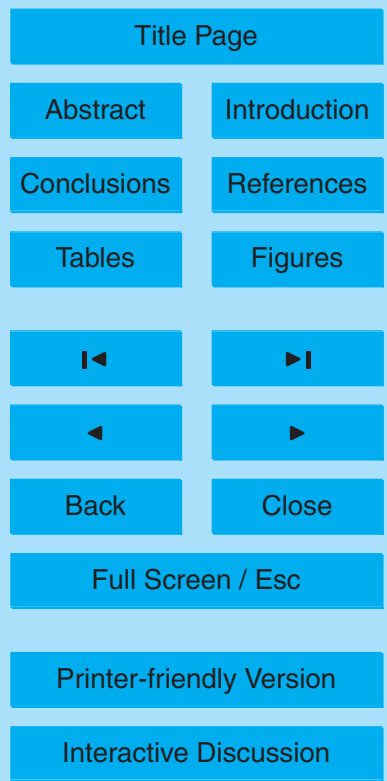


ranges of $3-\mathrm{HG}$ were $1.39-18.9 \mathrm{ng} \mathrm{m}^{-3}$ (average $7.02 \mathrm{ng} \mathrm{m}^{-3}$ ) at daytime and 0.39 $19.4 \mathrm{ng} \mathrm{m}^{-3}\left(6.66 \mathrm{ng} \mathrm{m}^{-3}\right)$ at nighttime. Concentration ranges of MBTCA were 3.94$24.2 \mathrm{ng} \mathrm{m}^{-3}\left(11.5 \mathrm{ng} \mathrm{m}^{-3}\right)$ at daytime and $3.47-25.9 \mathrm{ng} \mathrm{m}^{-3}\left(8.36 \mathrm{ng} \mathrm{m}^{-3}\right)$ at nighttime.

Regarding their high reactivity and relatively low vapor pressure, sesquiterpenes 5 have been the least studied BVOCs. Among sesquiterpenes emitted from the plants, $\beta$ caryophyllene is one of the most abundant species and most frequently reported (Duhl et al., 2008). $\beta$-Caryophyllinic acid, an ozonolysis or photo-oxidation product of $\beta$ caryophyllene (Jaoui et al., 2007), was identified at both daytime $\left(1.76-35.2 \mathrm{ng} \mathrm{m}^{-3}\right.$, average $12.5 \mathrm{ng} \mathrm{m}^{-3}$ ) and nighttime $\left(1.22-39.4 \mathrm{ng} \mathrm{m}^{-3}, 11.7 \mathrm{ng} \mathrm{m}^{-3}\right)$ samples without any significant differences. These values are similar to those reported in the aerosols from Hong Kong (Hu et al., 2008), Research Triangle Park, North Carolina (Lewandowski et al., 2007), but are about 2 orders of magnitude higher than those reported in the Arctic aerosols (Fu et al., 2009).

\subsection{Temporal variations}

15 In the previous study of the Mt. Tai aerosols (Fu et al., 2008), the temporal variation of levoglucosan, a tracer for biomass burning, showed two major peaks: one during 5-7 June (Event 1, E1) and the other during 12-14 June (Event 2, E2), as well as one minor peak on 27 June (Event 3, E3). Similar patterns were observed for other biomass burning tracers such as $\beta$-sitosterol, vanillic acid, and syringic acid (Fu et al., 2008). Thus, E1 and E2 were identified as major episodes of field burning of agricultural residues such as wheat straws in the CEC.

Figure 1 presents the overall temporal variations of the polar organic tracers. All the biogenic SOA tracers showed no clear diurnal trends, suggesting that they are formed over a relatively long period of time. The isoprene oxidation tracers showed very similar temporal trends each other (Fig. 1a-d). In addition to the peaks at E1, E2 and E3 when levoglucosan maximized, 2-methyltetrols showed some other peaks during 1-2 June and 19-22 June. Similar maxima can also be found in the temporal

\section{Formation of secondary organic aerosol over Mt. Tai during MTX2006}

P. Q. Fu et al.

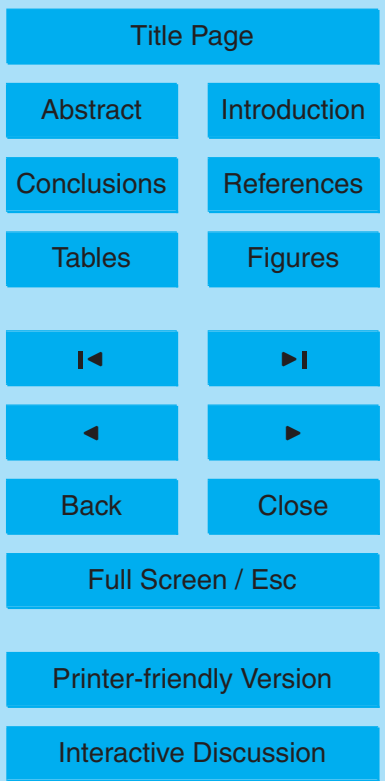


trends of monoterpene oxidation products (Fig. 1e-i) and malic acid (Fu et al., 2008). Malic acid is a secondary oxidation tracer of succinic acid (Kawamura and Ikushima, 1993).

A good correlation was found between the concentrations of 2-methyltetrols and $\mathrm{C}_{5}$ 5 alkene triols $\left(R^{2}=0.68\right.$, Fig. $\left.2 a\right)$ in the Mt. Tai samples. However, the concentration ratios of 2-methyltetrols to $\mathrm{C}_{5}$-alkene triols significantly varied (Fig. 3 ), suggesting that their formation pathways may be different. Wang et al. (2005) reported that these polyols are formed through diepoxy derivatives of isoprene, which can be converted into 2-methyltetrols through acid-catalyzed hydrolysis. Alternatively, the formation of $\mathrm{C}_{5}$ 10 alkene triols was explained through rearrangement reactions of hydroxyperoxy radicals that are formed in the initial photooxidation of isoprene (Surratt et al., 2006).

The temporal variations of monoterpene oxidation tracers (Fig. 1e-i) were different from those of isoprene oxidation tracers (Fig. 1a-d). Cahill et al. (2006) also reported a poor correlation between monoterpene oxidation products and 2-methyltetrols in moun15 tain aerosols. Interestingly, pinonic, norpinic, and pinic acids showed a peak during 810 June, which was not found for other polar tracers. In fact, a rain event occurred in the evening of 7 June, although the precipitation was rather small $(0.8 \mathrm{~mm})$. Air mass trajectory analysis showed that the source region of air masses that arrived over Mt. Tai have shifted from the South to the North China during this period (Fu et al., 2008).

20 Based on the levels of CO, ozone (Li et al., 2008), and levoglucosan (Fu et al., 2008), as well as air mass trajectories, we consider that a clean air mass may have intruded from the north over Mt. Tai during 8-10 June. However, MBTCA and 3-HG did not show a peak during this period. Because pinic and pinonic acids are lower-generation photooxidation products of $\alpha-/ \beta$-pinene compared to MBTCA and 3-HG (Kourtchev et al., 2009), the enhanced concentrations of pinic and pinonic acids during 8-10 June over Mt. Tai suggest that the photooxidation of $\alpha-/ \beta$-pinene was not completed. Concentration ratio of 3-HG plus MBTCA to pinic acid ((3HG+MBTCA)/pinic) also showed the lowest value during 8-10 June (Fig. 3).

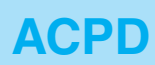

9, 16941-16972, 2009

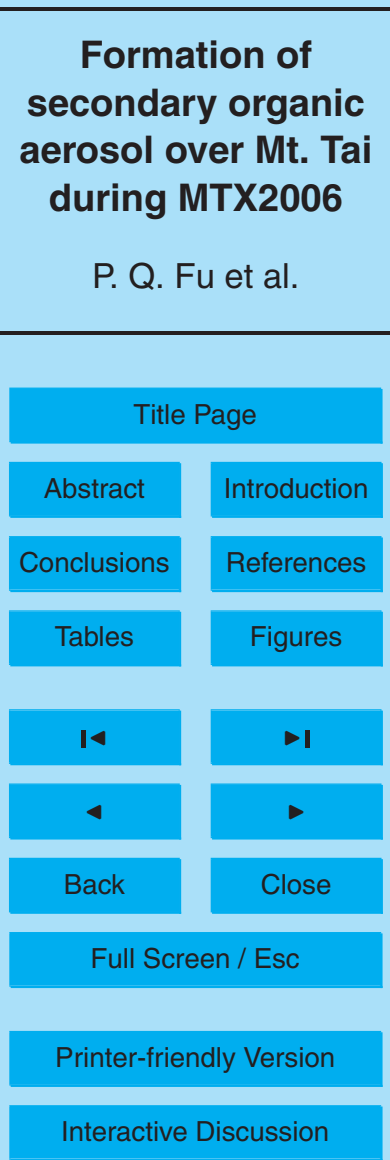

16950 
Temporal variations of $\beta$-caryophyllinic acid (Fig. 1j) showed two major peaks at $\mathrm{E} 1$ and E2. These peaks are substantially different from those of isoprene- or monoterpene-oxidation tracers (Fig. 1a-i). However, they are similar to those of OC, WSOC, and levoglucosan (Fu et al., 2008). Levoglucosan and $\beta$-caryophyllene ox5 idation products showed a positive correlation $\left(R^{2}=0.52\right.$, Fig. $\left.2 \mathrm{~b}\right)$, indicating that $\beta$ caryophyllinic acid detected over Mt. Tai was mainly originated from biomass burning process in early summer. However, no correlations were found between levoglucosan and isoprene or monoterpene SOA tracers. This is reasonable because the emissions of isoprene and monoterpenes are insignificant for most of the widely planted 10 crop species (Kesselmeier and Staudt, 1999), while the active field burning activities of wheat straws in the CEC during early summer may release levoglucosan and sesquiterpenes such as $\beta$-caryophyllene to a certain quantity. Another possibility is that a significant emission of OC during biomass burning may shift the gas/particle partitioning of $\beta$-caryophyllinic acid toward particle phase due to the adsorption by the preexisting 15 OC.

As reported in a previous study, dehydroabietic acid, a smoke marker of coniferous trees, showed a major peak during E3 (Fu et al., 2008), suggesting that E3 was associated with the biomass burning source that may be different from E1 and E2. During E3, air mass trajectory analysis showed that most of the air masses came from the 20 South China where the field burning of wheat straws was almost finished, but the harvest of wheat was still active in the north. Thus, the concentration peak of isoprene and monoterpene SOA tracers during E3 (Fig. 1) may originate from possible forest fire that may happen in the South China. Forest fires enhance the emissions of BVOCs.

\subsection{Hierarchical cluster analysis (HCA)}

25 In order to get a general view on the sources of biogenic SOA tracers detected in the tropospheric aerosols over Mt. Tai, HCA was applied to the present dataset together with the data of OC, levoglucosan, and malic acid using the squared Euclidean distance as a grouping criterion. As shown in Fig. 4, three clusters (1, 2 and 3 ) can be

\section{Formation of secondary organic aerosol over Mt. Tai during MTX2006}

P. Q. Fu et al.

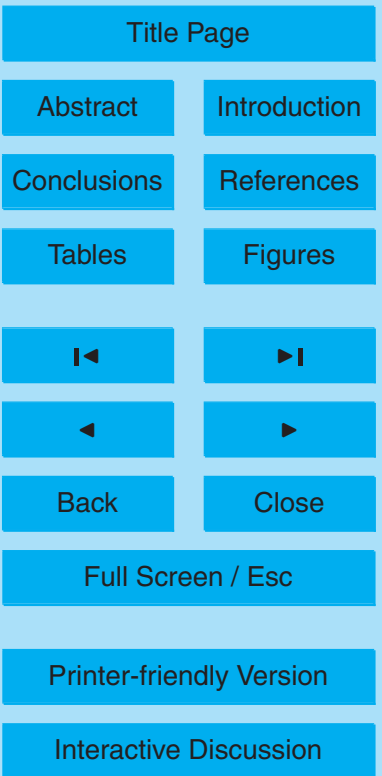

16951 
distinguished for both day- and night-time aerosols. At daytime, cluster 1 is composed of 3-hydroxyglutaric acid, malic acid, $\beta$-caryophyllinic acid, OC, and levoglucosan. Thus, cluster 1 should be mainly associated with the emissions from biomass burning. 3-Hydroxyglutaric acid was strongly correlated with malic acid $\left(R^{2}=0.91\right.$, Fig. $\left.2 \mathrm{c}\right)$, indi-

5 cating a similar formation pathway. Cluster 2 contains pinonic and pinic acids that are associated with the photooxidation of $\alpha$-/ $\beta$-pinene. Cluster 3 contains 2 -methylglyceric acid, $\mathrm{C}_{5}$-alkene triols and 2-methyltetrols, which are produced by the photooxidation of isoprene. Two monoterpene SOA tracers (norpinic acid and MBTCA) are also in cluster 3 , indicating that these compounds may be derived from same source regions 10 and/or have very similar atmospheric behaviors (such as gas/particle partitioning) with those of isoprene oxidation products.

At nighttime, cluster 1 contains the same pattern as those at daytime. Cluster 2 contains pinonic, pinic, and norpinic acids that are derived from the photochemical oxidation of $\alpha-/ \beta$-pinene. Cluster 3 contains isoprene oxidation products together with 15 MBTCA, which is a higher-generation photooxidation product of $\alpha$-/ $\beta$-pinene as mentioned above. It should be noted that in Fig. 4, only norpinic acid moved from daytime cluster 3 that is characterized with isoprene SOA tracers to nighttime cluster 2 that is associated with monoterpene SOA tracers (pinic and pinonic acids), indicating that norpinic acid may have formation pathways different from pinic and pinonic acids at daytime.

\subsection{Enhanced contribution of isoprene oxidation products}

In the Mt. Tai aerosols, total concentrations of isoprene SOA tracers $\left(202 \pm 123 \mathrm{ng} \mathrm{m}^{-3}\right.$ at daytime and $226 \pm 182 \mathrm{ng} \mathrm{m}^{-3}$ at nighttime) are 1 order of magnitude higher than those of the monoterpene SOA tracers (daytime $29.1 \pm 11.2 \mathrm{ng} \mathrm{m}^{-3}$ vs. nighttime $2522.5 \pm 9.85 \mathrm{ng} \mathrm{m}^{-3}$ ) (Table 1). This feature is different from the previous studies as summarized in Table 2, in which we propose a concentration ratio of total isoprene to monoterpene oxidation tracers $\left(R_{\text {iso/mono }}\right)$ to evaluate the relative contribution of iso-

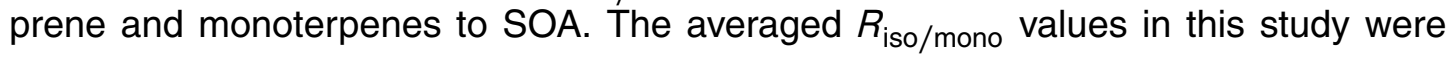
16952

\section{Formation of secondary organic aerosol over Mt. Tai during MTX2006}

P. Q. Fu et al.

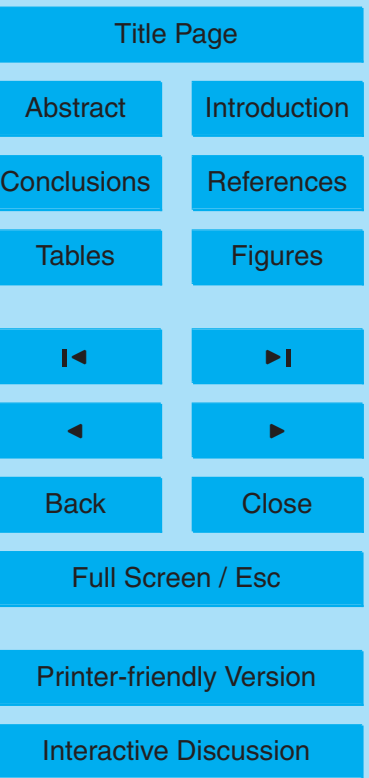


6.94 at daytime and 10.0 at nighttime. They are much higher than those reported from

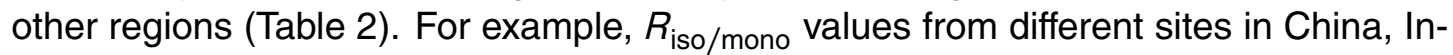
dia and Sierra Nevada, USA are slightly lower (2-6), but significantly lower in aerosols from NC, USA (0.89), Rishiri Island, Japan (0.85), and Jülich, Germany (0.80), and 5 Hong Kong, China (0.46). The ratios are further lower in PM1 samples from Hyytiälä, Finland (0.24-0.34). Interestingly, the lowest values $(0.08-0.24)$ were observed in the Canadian High Arctic, especially before polar sunrise (Fu et al., 2009). These comparisons indicate that the Mt. Tai aerosols are highly influenced by isoprene oxidation products compared to monoterpene oxidation products.

10 Average contribution of isoprene oxidation products to OC was found to be $0.603 \%$ at daytime and $0.643 \%$ at nighttime, which were $6-8$ times higher than those of monoterpene oxidation products $(0.102 \%$ at daytime and $0.076 \%$ nighttime) (Table 1$)$. The contributions of $\beta$-caryophyllinic acid to OC were $0.044 \%$ at daytime and $0.036 \%$ at nighttime. Because the mountaintop exists in the FT at night, higher contribution of 15 isoprene to SOA formation at nighttime $\left(R_{\text {iso/mono }}=10.0\right)$ than daytime $(6.94)$ may indicate the presence of a large source of organic aerosol in the FT (Heald et al., 2005). This also suggests that the isoprene oxidation products are more abundant than other biogenic SOA precursors in the atmosphere of high altitudes (Henze and Seinfeld, 2006).

20 The enhanced SOA formation from isoprene may be associated with greater emissions of isoprene than $\alpha-/ \beta$-pinene and $\beta$-caryophyllene in the studied region. Central East China is not only the biggest source region of anthropogenic trace gases in China (Li et al., 2008; Zhao et al., 2009), but also one of the most important source regions of isoprene in the world during summer (Guenther et al., 1995). Aerosol concentrations in 25 accumulation mode are suggested to be the highest in CEC (Andreae and Rosenfeld, 2008). Biogenic VOCs are quickly oxidized by $\mathrm{OH}, \mathrm{O}_{3}$ and/or $\mathrm{NO}_{3}$ (and occasionally chlorine atoms) in the atmosphere. Lifetimes of isoprene are on a scale of hours with respect to $\mathrm{OH}$ and $\mathrm{NO}_{3}$, and days with $\mathrm{O}_{3}$. Monoterpenes generally react with oxidants more quickly than isoprene does, with lifetimes of minutes to days. Sesquiterpenes

\section{Formation of secondary organic aerosol over Mt. Tai during MTX2006}

P. Q. Fu et al.

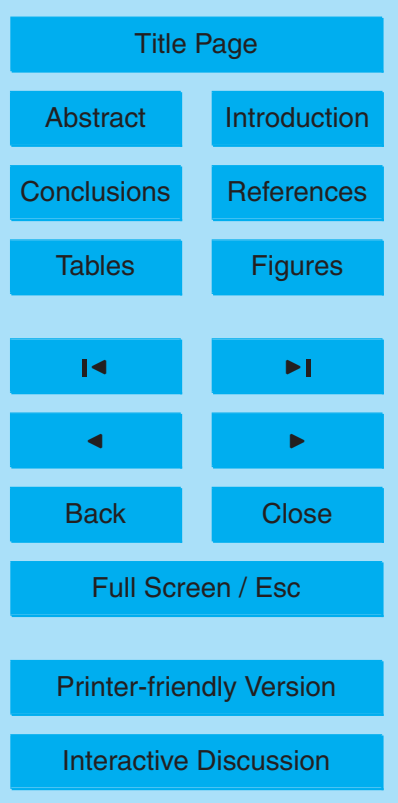

\section{3}


generally have shorter lifetimes of minutes to hours (Atkinson and Arey, 2003). During MTX2006, the atmospheric concentrations of isoprene over Mt. Tai were about twice higher than those of $\alpha$-/ $\beta$-pinene (Suthawaree and Kato, 2009), indicating that both of them (especially isoprene) were not completely oxidized during the transport from their 5 ground sources to the summit of Mt. Tai.

Another important factor is that the gas/particle partitioning of isoprene oxidation products can be affected by relatively low temperatures at the summit of Mt. Tai (10$25^{\circ} \mathrm{C}$ ) at nighttime, causing higher concentrations in aerosol phase. Concentrations of isoprene SOA tracers, especially 2-methyltetrols showed higher levels at nighttime 10 (average $226 \mathrm{ng} \mathrm{m}^{-3}$ ) than daytime $\left(202 \mathrm{ng} \mathrm{m}^{-3}\right)$, although monoterpene SOA tracers showed an opposite trend (Table 1).

Figure 5 shows the temporal variations of $R_{\text {iso/mono }}$ values, together with $\mathrm{O}_{3}$ and $\mathrm{NO}_{\mathrm{x}}$

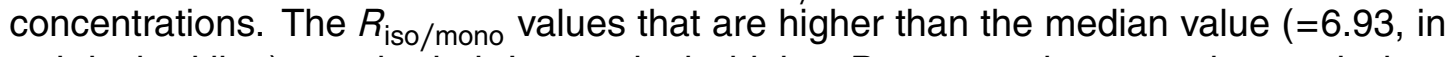
red dashed line) are shaded. Interestingly, higher $R_{\text {iso/mono values are observed when }}$ $15 \mathrm{O}_{3}$ and $\mathrm{NO}_{\mathrm{x}}$ concentrations are higher. The observed mean $\mathrm{O}_{3}$ concentration was very high ( $82 \mathrm{ppbv}$ ) during the sampling period, and the data of 14 days showed hourly ozone mixing ratios exceeding $100 \mathrm{ppbv}$, that is, China's air quality standard (Grade II) (Li et al., 2008). Such a high level of $\mathrm{O}_{3}$ at the summit of Mt. Tai in July 2003 has been reported by Gao et al. (2005). $\mathrm{O}_{3}$ is mainly produced by photochemical reactions involving $\mathrm{NO}_{\mathrm{x}}, \mathrm{CO}$ and VOCs. Ozone-isoprene reaction is a minor contributor to isoprene SOA formation compared to the reaction with $\mathrm{OH}$ (Kleindienst et al., 2007b). The midday peak concentration of $\mathrm{OH}$ during MTX2006 predicted by a photochemical box model was about $5.0 \times 10^{6} \mathrm{~cm}^{-3}$ with a maximum of $1.6 \times 10^{7} \mathrm{~cm}^{-3}$, and the $24-\mathrm{h}$ average concentrations were about $1.8 \times 10^{6} \mathrm{~cm}^{-3}$ (Kanaya et al., 2009). The relatively 25 high $\mathrm{OH}$ concentrations during the sampling period indicate that $\mathrm{OH}$ reaction would dominate the isoprene SOA formation.

Recently, Weber et al. (2007) found that biogenic SOA formation is correlated with anthropogenic tracers. Ervens et al. (2008) reported that SOA yield from cloudprocessing of isoprene oxidation products could be enhanced in regions with high $\mathrm{NO}_{\mathrm{x}}$

\section{Formation of secondary organic aerosol over Mt. Tai during MTX2006}

P. Q. Fu et al.

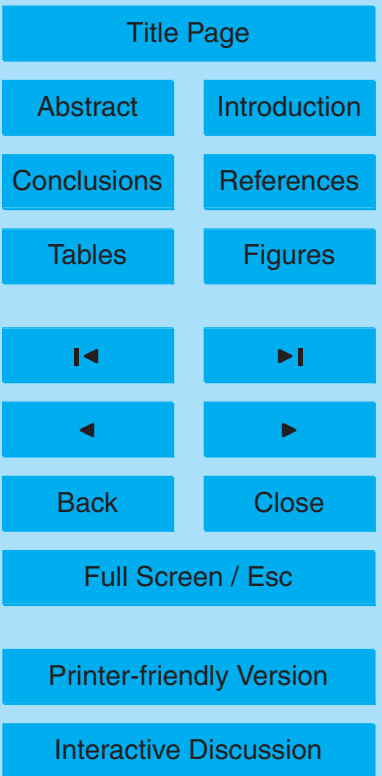


and isoprene emissions. These findings may further support the enhanced contribution of isoprene oxidation products in the present study. Alternatively, the co-variation of $R_{\text {iso/mono }}$ values with ozone and $\mathrm{NO}_{\mathrm{x}}$ concentrations may suggest that under high $\mathrm{NO}_{\mathrm{x}}$ and $\mathrm{OH}$ conditions, BVOCs, in particular, isoprene and their oxidation products can 5 act as important precursors for the photochemical production of ozone rather than its consumption. This assumption is supported by a photochemical box model study that biogenic hydrocarbons do contribute to the ozone production during the same campaign (Kanaya et al., 2009). Other studies have reported that the oxidation of BVOCs by $\mathrm{OH}$ in the presence of $\mathrm{NO}_{x}$ can be the primary source of tropospheric ozone (Ry10 erson et al., 2001). By comparing the measured isoprene emissions with estimated emissions of anthropogenic VOCs, Goldstein et al. (1998) also stated that isoprene is more important for ozone production in Massachusetts during hot summer days when the highest ozone events occur.

Except for Mt. Tai and Hong Kong aerosols, the $R_{\text {iso/mono }}$ values seem to depend 15 on latitude (Table 2 ). Higher $R_{\text {iso/mono }}$ values are generally observed in lower latitudes such as in South China (Hainan, 5.43) and tropical India (Chennai, 3.62), followed by those in mid-latitudes such as the northeastern China (Mt. Changbai), USA, Japan, and Germany. As mentioned earlier in this section, the lowest values are found in higher latitudes such as in Finland and the Canadian High Arctic at Alert. This latitudinal trend is in accordance with the global distribution of isoprene emission rate estimated by a global model in which tropical woodlands have high fluxes of isoprene $\left(>1 \mathrm{~g} \mathrm{C} \mathrm{m}^{-2}\right.$ month $^{-1}$ ) throughout the year (Guenther et al., 1995). They stated that high summertime isoprene fluxes are also common in some temperate zones including eastern China. In contrast, the highest monoterpene emission rates in July are 25 predicted for the western United States, eastern Canada, central Europe, and parts of the Amazon basin. Thus, we propose here that the $R_{\text {iso/mono value can be used as }}$ a tracer to estimate the contribution of isoprene and monoterpenes to biogenic SOA formation in various ecosystems.

\section{Formation of secondary organic aerosol over Mt. Tai during MTX2006}

P. Q. Fu et al.

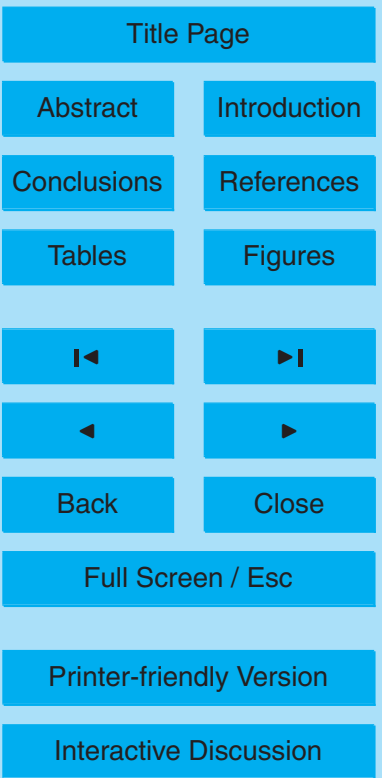




\subsection{Estimated contributions of BVOCs to secondary organic carbon}

Contributions of BVOCs to secondary organic carbon (SOC) were estimated using a tracer-based method reported by Kleindienst et al. (2007a). Using the measured concentrations of tracer compounds in the Mt. Tai aerosols and the laboratory5 derived tracer mass fraction $\left(f_{\text {soc }}\right)$ factors of $0.155 \pm 0.039$ for isoprene, $0.231 \pm 0.111$ for monoterpenes and $0.0230 \pm 0.0046$ for $\beta$-caryophyllene (Kleindienst et al., 2007a), we calculated the contributions of these precursors to ambient OC. As shown in Table 1 and Fig. 6 , we found that monoterpenes and $\beta$-caryophyllene are rather minor contributors to SOC during MTX2006.

10 The contributions of monoterpenes to SOC ranged from 0.05 to $0.22 \mu \mathrm{gC} \mathrm{m}^{-3}$ (average $\left.0.13 \mu \mathrm{gC} \mathrm{m}^{-3}\right)$ at daytime and 0.02 to $0.21 \mu \mathrm{gC} \mathrm{m}^{-3}\left(0.10 \mu \mathrm{gC} \mathrm{m}^{-3}\right)$ at nighttime (Table 1). For $\beta$-caryophyllene, the contributions were $0.08-1.53 \mu \mathrm{gC} \mathrm{m}^{-3}$ $\left(0.54 \mu \mathrm{gC} \mathrm{m}^{-3}\right)$ and $0.05-1.71 \mu \mathrm{gC} \mathrm{m}^{-3}\left(0.51 \mu \mathrm{gC} \mathrm{m}^{-3}\right)$, respectively. Hu et al. (2008) mentioned that acidic isomers of $\beta$-caryophyllinic acid could be formed from the pho15 tooxidation of other sesquiterpenes having an endocylic $\mathrm{C}=\mathrm{C}$ bond, which might co-elute with $\beta$-caryophyllinic acid. Therefore, the estimated contribution of $\beta$ caryophyllene SOC may represent a broader class of sesquiterpenes. The isoprenebased tracers (2-methylglyceric acid and 2-methyltetrols) were calculated to be 0.24 $2.79 \mu \mathrm{gC} \mathrm{m}^{-3}\left(1.09 \mu \mathrm{gC} \mathrm{m}^{-3}\right)$ at daytime and $0.05-4.26 \mu \mathrm{gC} \mathrm{m}^{-3}\left(1.25 \mu \mathrm{gC} \mathrm{m}^{-3}\right)$ at 20 nighttime. These values are similar to those reported at Research Triangle Park, NC (Kleindienst et al., 2007a) and Hong Kong (Hu et al., 2008), but are about 2-3 orders of magnitude higher than those reported in the Canadian High Arctic (Fu et al., 2009).

As shown in Table 1, the total SOC derived from isoprene, monoterpenes and sesquiterpene in the Mt. Tai aerosols ranged from 0.46 to $3.45 \mu \mathrm{gC} \mathrm{m}^{-3}$ (average $\left.251.76 \mu \mathrm{gC} \mathrm{m}^{-3}\right)$ at daytime and 0.12 to $4.89 \mu \mathrm{gC} \mathrm{m}^{-3}\left(1.85 \mu \mathrm{gC} \mathrm{m}^{-3}\right)$ at nighttime, which account for $11.2 \%$ and $11.0 \%$ of the OC at day- and night-time, respectively. As shown in Fig. 6, the temporal variation of total SOC\% in OC maximized (up to $32.5 \%$ ) during 18-21 June when the daytime ambient temperature became highest. In contrast, a

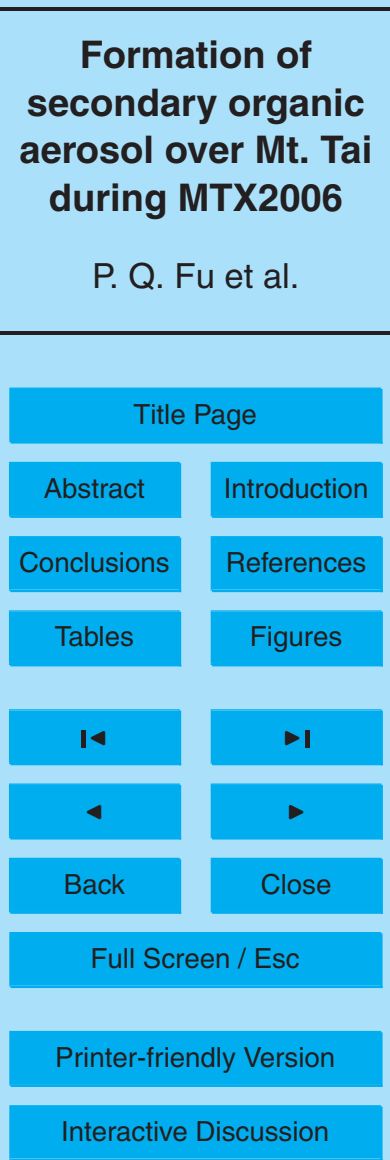


minimum (3.27\%) was found during 8-10 June when the clean air mass came from the north through the FT. Isoprene is clearly found to be the largest SOC contributor in the Mt. Tai aerosols (Fig. 6), accounting for $62.2 \%$ and $67.3 \%$ of BVOC-derived SOC at day- and night-time, respectively. This is consistent with the results reported by Klein-

5 dienst et al. (2007a) that isoprene was the largest contributor in the summer aerosols collected at Research Triangle Park, North Carolina.

\section{Conclusions}

In this study, biogenic SOA tracers of isoprene, monoterpenes, and $\beta$-caryophyllene were measured in tropospheric aerosols collected during a summer field campaign conducted at the summit of Mt. Tai $(1534 \mathrm{~m})$, Central East China. Their total concentrations exhibited no diurnal variations, ranging from 62.9 to $542 \mathrm{ng} \mathrm{m}^{-3}$ (average $\left.244 \mathrm{ng} \mathrm{m}^{-3}\right)$ at daytime and 21.8 to $834 \mathrm{ng} \mathrm{m}^{-3}\left(260 \mathrm{ng} \mathrm{m}^{-3}\right)$ at nighttime, which account for $0.75 \%$ and $0.76 \%$ of OC in the mountain aerosols. $\beta$-Caryophyllinic acid showed a temporal pattern similar to those of $\mathrm{OC}$ and levoglucosan. This compound 15 may originate from the biomass burning activities that maximized in Central East China during early summer. However, isoprene and monoterpene tracers showed different temporal patterns.

Due to the tracer-based calculation, the contributions of BVOCs to SOC were estimated using the ambient concentrations of biogenic SOA tracers. On average, the 20 isoprene-derived SOC is about 10 and 2 times higher than those of monoterpene- and $\beta$-caryophyllene-derived SOC, respectively. Higher contribution of isoprene oxidation products to SOA formation may be explained by larger isoprene emissions in this region, together with relatively high levels of $\mathrm{OH}, \mathrm{O}_{3}$ and $\mathrm{NO}_{\mathrm{x}}$ in Central East China in summer. High levels of pollutants may enhance the SOA formation rates, which affect the gas/particle partitioning of the BVOCs oxidation products. This situation also changes the formation pathways of SOA tracers, and produces inorganic salts (i.e. ammonium sulfate) and organic acids (i.e. dicarboxylic acids) to alter the hygroscopic

\section{Formation of secondary organic aerosol over Mt. Tai during MTX2006}

P. Q. Fu et al.

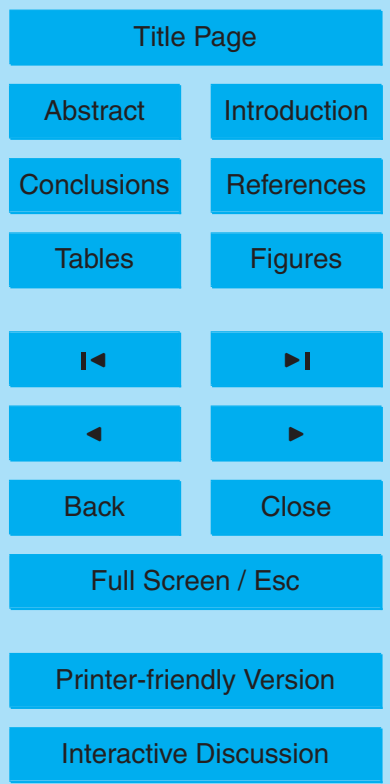


property of particle. Hence, high loading of organic aerosols (the averaged OC levels were $18.6 \mu \mathrm{g} \mathrm{m}^{-3}$ at daytime and $20.5 \mu \mathrm{g} \mathrm{m}^{-3}$ at nighttime) in the Mt. Tai aerosols may influence the gas/particle partitioning processes. Such a high isoprene-derived SOA observed in the high altitudinal aerosols over Mt. Tai is consistent with previous findings 5 from model study that isoprene oxidation products have much greater concentrations at higher altitudes or from aircraft observation that very high OC values over Northwest Pacific during the ACE-Asia campaign.

Acknowledgements. We thank K. Okuzawa and S. G. Aggarwal for their help during the sample collection and J. Chen for HCA analysis. This study is supported by the Japanese Min10 istry of Education, Culture, Sports, Science and Technology (MEXT) through grant-in-aid Nos. 17340166 and 19204055 . P.F. appreciates the Japan Society for the Promotion of Science (JSPS) for a research fellowship. We also acknowledge the financial support by the Global Environment Research Fund (B-051) of the Ministry of the Environment, Japan for the shipping of the instruments to Mt. Tai.

\section{References}

Andreae, M. O. and Rosenfeld, D.: Aerosol-cloud-precipitation interactions. Part 1, The nature and sources of cloud-active aerosols, Earth-Sci. Rev., 89, 13-41, 2008.

Atkinson, R. and Arey, J.: Gas-phase tropospheric chemistry of biogenic volatile organic compounds: a review, Atmos. Environ., 37, 197-219, 2003.

Böge, O., Miao, Y., Plewka, A., and Herrmann, H.: Formation of secondary organic particle phase compounds from isoprene gas-phase oxidation products: An aerosol chamber and field study, Atmos. Environ., 40, 2501-2509, 2006.

Bhat, S. and Fraser, M. P.: Primary source attribution and analysis of $\alpha$-pinene photooxidation products in Duke Forest, North Carolina, Atmos. Environ., 41, 2958-2966, 2007.

25 Cahill, T. M., Seaman, V. Y., Charles, M. J., Holzinger, R., and Goldstein, A. H.: Secondary organic aerosols formed from oxidation of biogenic volatile organic compounds in the Sierra Nevada Mountains of California, J. Geophys. Res.-Atmos., 111, D16312, doi:10.1029/2006JD007178, 2006.

\section{Formation of secondary organic aerosol over Mt. Tai during MTX2006}

P. Q. Fu et al.

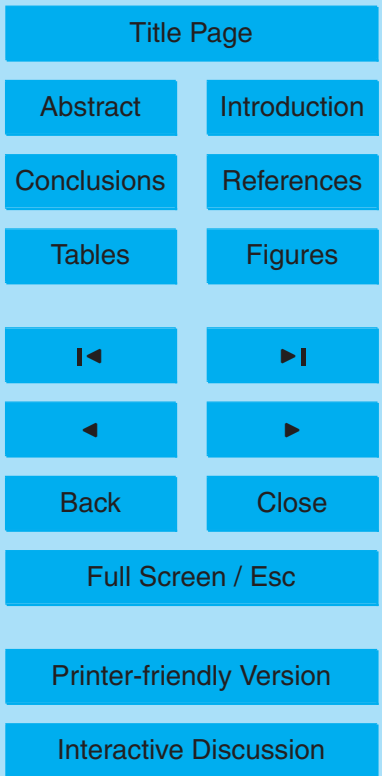


Claeys, M., Graham, B., Vas, G., Wang, W., Vermeylen, R., Pashynska, V., Cafmeyer, J., Guyon, P., Andreae, M. O., Artaxo, P., and Maenhaut, W.: Formation of secondary organic aerosols through photooxidation of isoprene, Science, 303, 1173-1176, 2004a.

Claeys, M., Wang, W., Ion, A. C., Kourtchev, I., Gelencsér, A., and Maenhaut, W.: Formation of secondary organic aerosols from isoprene and its gas-phase oxidation products through reaction with hydrogen peroxide, Atmos. Environ., 38, 4093-4098, 2004b.

Claeys, M., Szmigielski, R., Kourtchev, I., van der Veken, P., Vermeylen, R., Maenhaut, W., Jaoui, M., Kleindienst, T. E., Lewandowski, M., Offenberg, J., and Edney, E. O.: Hydroxydicarboxylic acids: Markers for secondary organic aerosol from the photooxidation of $\alpha$-pinene,

10 Environ. Sci. Technol., 41, 1628-1634, 2007.

Clements, A. L. and Seinfeld, J. H.: Detection and quantification of 2-methyltetrols in ambient aerosol in the southeastern United States, Atmos. Environ., 41, 1825-1830, 2007.

Ding, X., Zheng, M., Yu, L., Zhang, X., Weber, R. J., Yan, B., Russell, A. G., Edgerton, E., and Wang, X.: Spatial and seasonal trends in biogenic secondary organic aerosol tracers and water-soluble organic carbon in the southeastern United States, Environ. Sci. Technol., 42, 5171-5176, 2008.

Duhl, T. R., Helmig, D., and Guenther, A.: Sesquiterpene emissions from vegetation: a review, Biogeosciences, 5, 761-777, 2008, http://www.biogeosciences.net/5/761/2008/.

20 Edney, E. O., Kleindienst, T. E., Jaoui, M., Lewandowski, M., Offenberg, J. H., Wang, W., and Claeys, M.: Formation of 2-methyltetrols and 2-methylglyceric acid in secondary organic aerosol from laboratory irradiated isoprene/ $\mathrm{NO}_{\mathrm{x}} / \mathrm{SO}_{2} /$ air mixtures and their detection in ambient $\mathrm{PM}_{2.5}$ samples collected in the eastern United States, Atmos. Environ., 39, 5281-5289, 2005.

Ervens, B., Carlton, A. G., Turpin, B. J., Altieri, K. E., Kreidenweis, S. M., and Feingold, G.: Secondary organic aerosol yields from cloud-processing of isoprene oxidation products, Geophys. Res. Lett., 35, L02816, doi:10.1029/2007GL031828, 2008.

Fu, P., Kawamura, K., Okuzawa, K., Aggarwal, S. G., Wang, G., Kanaya, Y., and Wang, Z.: Organic molecular compositions and temporal variations of summertime moun30 tain aerosols over Mt. Tai, North China Plain, J. Geophys. Res.-Atmos., 113, D19107, doi:10.1029/2008JD009900, 2008.

Fu, P., Kawamura, K., Chen, J., and Barrie, L. A.: Isoprene, monoterpene, and sesquiterpene oxidation products in the high Arctic aerosols during late winter to early summer, Environ.

\section{Formation of secondary organic aerosol over Mt. Tai during MTX2006}

P. Q. Fu et al.

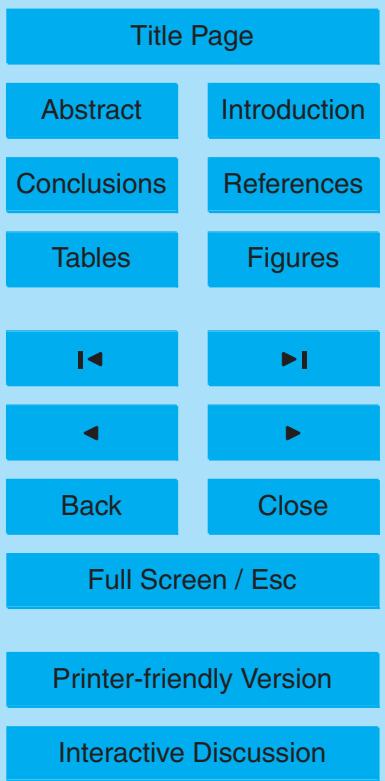


Sci. Technol., 43, 4022-4028, 2009.

Gao, J., Wang, T., Ding, A., and Liu, C.: Observational study of ozone and carbon monoxide at the summit of mount Tai (1534 ma.s.l.) in central-eastern China, Atmos. Environ., 39, 4779-4791, 2005.

5 Glasius, M., Lahaniati, M., Calogirou, A., Di Bella, D., Jensen, N. R., Hjorth, J., Kotzias, D., and Larsen, B. R.: Carboxylic acids in secondary aerosols from oxidation of cyclic monoterpenes by ozone, Environ. Sci. Technol., 34, 1001-1010, 2000.

Goldstein, A. H., Goulden, M. L., Munger, J. W., Wofsy, S. C., and Geron, C. D.: Seasonal course of isoprene emissions from a midlatitude deciduous forest, J. Geophys. Res., 103, $10 \quad 31045-31056,1998$.

Guenther, A., Hewitt, C. N., Erickson, D., Fall, R., Geron, C., Graedel, T., Harley, P., Klinger, L., Lerdau, M., McKay, W. A., Pierce, T., Scholes, B., Tallamraju, R., Taylor, J., and Zimmerman, P.: A global model of natural volatile organic compound emissions, J. Geophys. Res., 100, 8873-8892, 1995.

Guenther, A., Karl, T., Harley, P., Wiedinmyer, C., Palmer, P. I., and Geron, C.: Estimates of global terrestrial isoprene emissions using MEGAN (Model of Emissions of Gases and Aerosols from Nature), Atmos. Chem. Phys., 6, 3181-3210, 2006, http://www.atmos-chem-phys.net/6/3181/2006/.

Heald, C. L., Jacob, D. J., Park, R. J., Russell, L. M., Huebert, B. J., Seinfeld, J. H., Liao, H., and Weber, R. J.: A large organic aerosol source in the free troposphere missing from current models, Geophys. Res. Lett., 32, L18809, doi:10.1029/2005GL023831, 2005.

Henze, D. K. and Seinfeld, J. H.: Global secondary organic aerosol from isoprene oxidation, Geophys. Res. Lett., 33, L09812, doi:10.1029/2006GL025976, 2006.

Hoffmann, T., Odum, J. R., Bowman, F., Collins, D., Klockow, D., Flagan, R. C., and Seinfeld, J. H.: Formation of organic aerosols from the oxidation of biogenic hydrocarbons, J. Atmos. Chem., 26, 189-222, 1997.

Hu, D., Bian, Q., Li, T. W. Y., Lau, A. K. H., and Yu, J. Z.: Contributions of isoprene, monoterpenes, $\beta$-caryophyllene, and toluene to secondary organic aerosols in Hong Kong during the summer of 2006, J. Geophys. Res.-Atmos., 113, D22206, doi:10.1029/2008JD010437, 2008

linuma, Y., Böge, O., Gnauk, T., and Herrmann, $\mathrm{H} .:$ Aerosol-chamber study of the $\alpha$-pinene $/ \mathrm{O}_{3}$ reaction: influence of particle acidity on aerosol yields and products, Atmos. Environ., 38, 761-773, 2004.

\section{Formation of secondary organic aerosol over Mt. Tai during MTX2006}

P. Q. Fu et al.

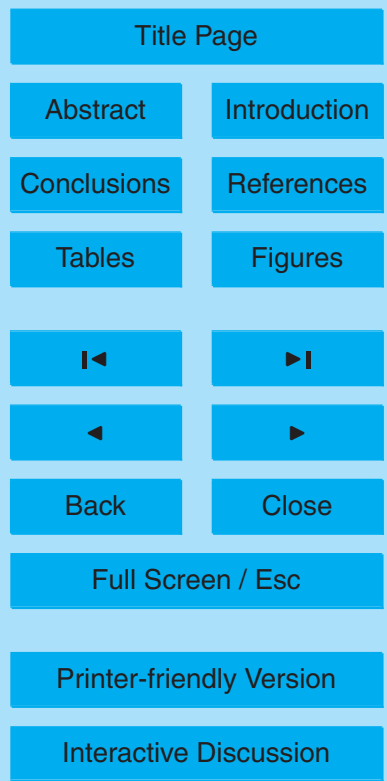


Ion, A. C., Vermeylen, R., Kourtchev, I., Cafmeyer, J., Chi, X., Gelencsér, A., Maenhaut, W., and Claeys, M.: Polar organic compounds in rural $\mathrm{PM}_{2.5}$ aerosols from K-puszta, Hungary, during a 2003 summer field campaign: Sources and diel variations, Atmos. Chem. Phys., 5, 1805-1814, 2005, http://www.atmos-chem-phys.net/5/1805/2005/.

Jang, M. and Kamens, R. M.: Newly characterized products and composition of secondary aerosols from the reaction of $\alpha$-pinene with ozone, Atmos. Environ., 33, 459-474, 1998.

Jaoui, M., Kleindienst, T. E., Lewandowski, M., Offenberg, J. H., and Edney, E. O.: Identification and quantification of aerosol polar oxygenated compounds bearing carboxylic or hydroxyl groups, 2, Organic tracer compounds from monoterpenes, Environ. Sci. Technol., 39, 56615673, 2005.

Jaoui, M., Lewandowski, M., Kleindienst, T. E., Offenberg, J. H., and Edney, E. O.: $\beta$ Caryophyllinic acid: An atmospheric tracer for $\beta$-caryophyllene secondary organic aerosol, Geophys. Res. Lett., 34, L05816, doi:10.1029/2006GL028827, 2007.

Kanakidou, M., Seinfeld, J. H., Pandis, S. N., Barnes, I., Dentener, F. J., Facchini, M. C., Van Dingenen, R., Ervens, B., Nenes, A., Nielsen, C. J., Swietlicki, E., Putaud, J. P., Balkanski, Y., Fuzzi, S., Horth, J., Moortgat, G. K., Winterhalter, R., Myhre, C. E. L., Tsigaridis, K., Vignati, E., Stephanou, E. G., and Wilson, J.: Organic aerosol and global climate modelling: a review, Atmos. Chem. Phys., 5, 1053-1123, 2005,

20 http://www.atmos-chem-phys.net/5/1053/2005/.

Kanaya, Y., Pochanart, P., Liu, Y., Li, J., Tanimoto, H., Kato, S., Suthawaree, J., Inomata, S., Taketani, F., Okuzawa, K., Kawamura, K., Akimoto, H., and Wang, Z. F.: Rates and regimes of photochemical ozone production over Central East China in June 2006: a box model analysis using comprehensive measurements of ozone precursors, Atmos. Chem. Phys. Discuss., 9, 12965-12997, 2009, http://www.atmos-chem-phys-discuss.net/9/12965/2009/.

Kavouras, I. G., Mihalopoulos, N., and Stephanou, E. G.: Formation of atmospheric particles from organic acids produced by forests, Nature, 395, 683-686, 1998.

Kavouras, I. G., Mihalopoulos, N., and Stephanou, E. G.: Formation and gas/particle partition30 ing of monoterpenes photo-oxidation products over forests, Geophys. Res. Lett., 26, 55-58, 1999.

Kavouras, I. G. and Stephanou, E. G.: Direct evidence of atmospheric secondary organic aerosol formation in forest atmosphere through hetermolecular nucleation, Environ. Sci.

\section{Formation of secondary organic aerosol over Mt. Tai during MTX2006}

P. Q. Fu et al.

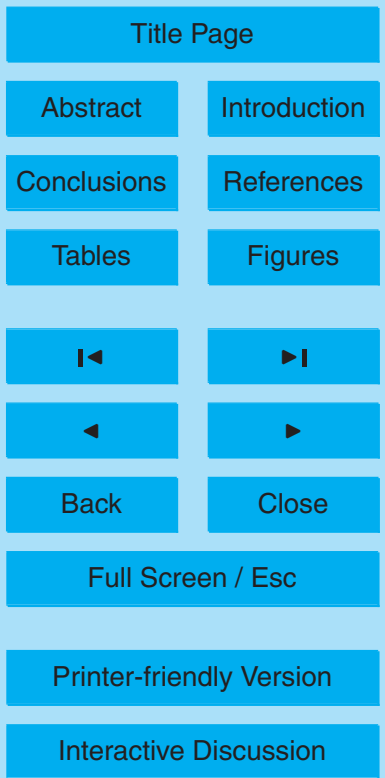


Technol., 36, 5083-5091, 2002.

Kawamura, K. and Ikushima, K.: Seasonal changes in the distribution of dicarboxylic acids in the urban atmosphere, Environ. Sci. Technol., 27, 2227-2235, 1993.

Kesselmeier, J. and Staudt, M.: Biogenic volatile organic compounds (VOC): an overview on emission, physiology and ecology, J. Atmos. Chem., 33, 23-88, 1999.

Kleindienst, T. E., Jaoui, M., Lewandowski, M., Offenberg, J. H., Lewis, C. W., Bhave, P. V., and Edney, E. O.: Estimates of the contributions of biogenic and anthropogenic hydrocarbons to secondary organic aerosol at a southeastern US location, Atmos. Environ., 41, 8288-8300, 2007a.

10 Kleindienst, T. E., Lewandowski, M., Offenberg, J. H., Jaoui, M., and Edney, E. O.: Ozoneisoprene reaction: Re-examination of the formation of secondary organic aerosol, Geophys. Res. Lett., 34, L01805, doi:10.1029/2006GL027485, 2007b.

Kourtchev, I., Ruuskanen, T., Maenhaut, W., Kulmala, M., and Claeys, M.: Observation of 2methyltetrols and related photo-oxidation products of isoprene in boreal forest aerosols from

15 Hyytiälä, Finland, Atmos. Chem. Phys., 5, 2761-2770, 2005, http://www.atmos-chem-phys.net/5/2761/2005/.

Kourtchev, I., Ruuskanen, T. M., Keronen, P., Sogacheva, L., Dal Maso, M., Reissell, A., Chi, X., Vermeylen, R., Kulmala, M., Maenhaut, W. and Claeys, M.: Determination of isoprene and $\alpha-/ \beta$-pinene oxidation products in boreal forest aerosols from Hyytiälä, Finland: diel 20 variations and possible link with particle formation events, Plant Biol., 10, 138-149, 2008a.

Kourtchev, I., Warnke, J., Maenhaut, W., Hoffmann, T., and Claeys, M.: Polar organic marker compounds in $\mathrm{PM}_{2.5}$ aerosol from a mixed forest site in western Germany, Chemosphere, 73, 1308-1314, 2008b.

Kourtchev, I., Copolovici, L., Claeys, M., and Maenhaut, W.: Characterization of atmospheric 25 aerosols at a forested site in Central Europe, Environ. Sci. Technol., 4665-4671, 2009.

Lewandowski, M., Jaoui, M., Kleindienst, T. E., Offenberg, J. H., and Edney, E. O.: Composition of $\mathrm{PM}_{2.5}$ during the summer of 2003 in Research Triangle Park, North Carolina, Atmos. Environ., 41, 4073-4083, 2007.

Li, J., Wang, Z., Akimoto, H., Yamaji, K., Takigawa, M., Pochanart, P., Liu, Y., Tanimoto, H., 30 and Kanaya, Y.: Near-ground ozone source attributions and outflow in central eastern China during MTX2006, Atmos. Chem. Phys., 8, 7335-7351, 2008, http://www.atmos-chem-phys.net/8/7335/2008/.

Ma, Y., Willcox, T. R., Russell, A. T., and Marston, G.: Pinic and pinonic acid formation in the

\section{Formation of secondary organic aerosol over Mt. Tai during MTX2006}

P. Q. Fu et al.

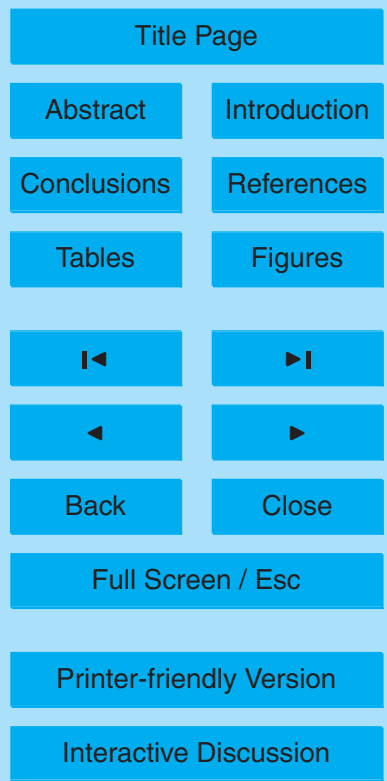


reaction of ozone with $\alpha$-pinene, Chem. Commun., 1328-1330, 2007.

Pöschl, U.: Atmospheric aerosols: Composition, transformation, climate and health effects, Angew. Chem. Int. Edit, 44, 7520-7540, 2005.

Plewka, A., Gnauk, T., Bruggemann, E., and Herrmann, H.: Biogenic contributions to the chemical composition of airborne particles in a coniferous forest in Germany, Atmos. Environ., 40, 103-115, 2006.

Pochanart, P., Kanaya, Y., Li, J., Komazaki, Y., Akimoto, H., Liu, Y., Wang, X., and Wang, Z.: Surface ozone, carbon monoxide, and black carbon over Central East China during MTX2006, Atmos. Chem. Phys. Discuss., submitted, 2009.

10 Ryerson, T. B., Trainer, M., Holloway, J. S., Parrish, D. D., Huey, L. G., Sueper, D. T., Frost, G. J., Donnelly, S. G., Schauffler, S., Atlas, E. L., Kuster, W. C., Goldan, P. D., Hubler, G., Meagher, J. F., and Fehsenfeld, F. C.: Observations of ozone formation in power plant plumes and implications for ozone control strategies, Science, 292, 719-723, 2001.

Seinfeld, J. H. and Pandis, S. N.: Atmospheric Chemistry and Physics, John Wiley \& Sons, New York, 2006.

Surratt, J. D., Murphy, S. M., Kroll, J. H., Ng, N. L., Hildebrandt, L., Sorooshian, A., Szmigielski, R., Vermeylen, R., Maenhaut, W., Claeys, M., Flagan, R. C., and Seinfeld, J. H.: Chemical composition of secondary organic aerosol formed from the photooxidation of isoprene, J. Phys. Chem. A, 110, 9665-9690, 2006.

20 Suthawaree, J., Kato, S., Okuzawa, K., Kanaya, Y., Pochanart, P., Akimoto, H., Wang, Z., and Kajii, Y.: Measurements of volatile organic compounds in the middle of Central East China during Mount Tai Experiment 2006 (MTX2006): observation of regional background and impact of biomass burning, Atmos. Chem. Phys. Discuss., 9, 16715-16753, 2009, http://www.atmos-chem-phys-discuss.net/9/16715/2009/.

Szmigielski, R., Surrat, J. D., González, G., Van der Veken, P., Kourtchev, I., Vermeylen, R., Blockhuys, F., Jaoui, M., Kleindienst, T. E., Lewandowski, M., Offenberg, J. H., Edney, E. O., Seinfeld, J. H., Maenhaut, W., and Claeys, M.: 3-Methyl-1,2,3-butanetricarboxylic acid: An atmospheric tracer for terpene secondary organic aerosol, Geophys. Res. Lett., 34, L24811, doi:10.1029/2007GL031338, 2007a.

30 Szmigielski, R., Surrat, J. D., Vermeylen, R., Szmigielska, K., Kroll, J. H., Ng, N. L., Murphy, S. M., Sorooshian, A., Seinfeld, J. H., and Claeys, M.: Characterization of 2-methylglyceric acid oligomers in secondary organic aerosol formed from the photooxidation of isoprene using trimethylsilylation and gas chromatography/ion trap mass spectrometry, J. Mass Spectrom.,

\section{Formation of secondary organic aerosol over Mt. Tai during MTX2006}

P. Q. Fu et al.

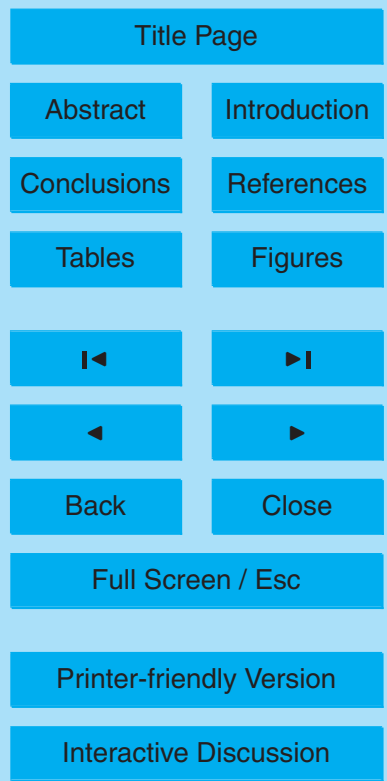


42, 101-116, 2007b.

Tunved, P., Hansson, H. C., Kerminen, V. M., Strom, J., Dal Maso, M., Lihavainen, H., Viisanen, Y., Aalto, P. P., Komppula, M., and Kulmala, M.: High natural aerosol loading over boreal forests, Science, 312, 261-263, 2006.

5 Wang, W., Kourtchev, I., Graham, B., Cafmeyer, J., Maenhaut, W., and Claeys, M.: Characterization of oxygenated derivatives of isoprene related to 2-methyltetrols in Amazonian aerosols using trimethylsilylation and gas chromatography/ion trap mass spectrometry, Rapid Commun. Mass Sp., 19, 1343-1351, 2005.

Wang, W., Wu, M. H., Li, L., Zhang, T., Liu, X. D., Feng, J. L., Li, H. J., Wang, Y. J., Sheng, G. Y., Claeys, M., and Fu, J. M.: Polar organic tracers in $\mathrm{PM}_{2.5}$ aerosols from forests in eastern China, Atmos. Chem. Phys., 8, 7507-7518, 2008, http://www.atmos-chem-phys.net/8/7507/2008/.

Weber, R. J., Sullivan, A. P., Peltier, R. E., Russell, A., Yan, B., Zheng, M., de Gouw, J., Warneke, C., Brock, C., Holloway, J. S., Atlas, E. L., and Edgerton, E.: A study of secondary organic aerosol formation in the anthropogenic-influenced southeastern United States, J. Geophys. Res.-Atmos., 112, D13302, doi:10.1029/2007JD008408, 2007.

Xia, X. and Hopke, P. K.: Seasonal variation of 2-methyltetrols in ambient air samples, Environ. Sci. Technol., 40, 6934-6937, 2006.

Yan, B., Zheng, M., Hu, Y. T., Lee, S., Kim, H. K., and Russell, A. G.: Organic composition of carbonaceous aerosols in an aged prescribed fire plume, Atmos. Chem. Phys., 8, 63816394, 2008,

http://www.atmos-chem-phys.net/8/6381/2008/.

Yu, J. Z., Cocker, D. R., Griffin, R. J., Flagan, R. C., and Seinfeld, J. H.: Gas-phase ozone oxidation products of monoterpenes: gaseous and particulate products, J. Atmos. Chem., 34, 207-258, 1999.

Zhao, C., Wang, Y., and Zeng, T.: East China Plains: A "basin" of ozone pollution, Environ. Sci. Technol., 43, 1911-1915, 2009.

\section{Formation of secondary organic aerosol over Mt. Tai during MTX2006}

P. Q. Fu et al.

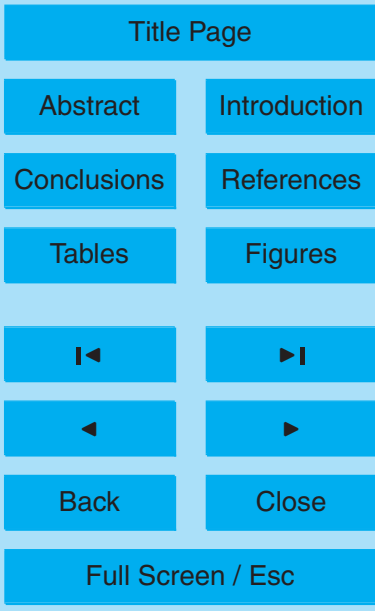

Printer-friendly Version

Interactive Discussion 
Table 1. Concentrations of biogenic SOA tracers measured in the tropospheric aerosols over Mt. Tai, Central East China $\left(\mathrm{ng} \mathrm{m}^{-3}\right)$.

\begin{tabular}{|c|c|c|c|c|c|c|c|c|c|c|}
\hline \multirow[b]{2}{*}{ Species } & \multicolumn{5}{|c|}{ Daytime $(n=19)$} & \multicolumn{5}{|c|}{ Nighttime $(n=20)$} \\
\hline & average & $\operatorname{std}^{a}$ & $\min$ & $\max$ & $\% \mathrm{C}$ in $\mathrm{OC}$ & average & std & $\min$ & $\max$ & $\% \mathrm{C}$ in $\mathrm{OC}$ \\
\hline $\mathrm{OC}\left(\mu \mathrm{g} \mathrm{m}^{-3}\right)$ & 18.6 & 10.4 & 5.1 & 47.5 & - & 20.5 & 16.8 & 2.5 & 67.2 & - \\
\hline \multicolumn{11}{|c|}{ Tracers for isoprene SOA } \\
\hline 2-methylglyceric acid & 51.5 & 31.4 & 12.7 & 110 & 0.143 & 45.7 & 30.0 & 4.28 & 110 & 0.116 \\
\hline$\sum \mathrm{C}_{5}$-alkene triols ${ }^{\mathrm{b}}$ & 32.7 & 20.8 & 7.70 & 83.7 & 0.114 & 32.0 & 26.9 & 4.68 & 116 & 0.110 \\
\hline 2-methylthreitol & 38.6 & 27.4 & 5.96 & 102 & 0.111 & 50.4 & 47.0 & 0.86 & 184 & 0.137 \\
\hline 2-methylerythritol & 79.5 & 58.3 & 14.3 & 222 & 0.235 & 97.4 & 87.1 & 1.83 & 366 & 0.280 \\
\hline subtotal & 202 & 123 & 44.8 & 500 & 0.603 & 226 & 182 & 15.5 & 777 & 0.643 \\
\hline $\mathrm{SOC}_{\text {isoprene }}^{\mathrm{c}}\left(\mu \mathrm{gC} \mathrm{m}^{-3}\right)$ & 1.09 & 0.69 & 0.24 & 2.79 & 7.4 & 1.25 & 1.02 & 0.05 & 4.26 & 8.0 \\
\hline \multicolumn{11}{|c|}{ Tracers for monoterpene SOA } \\
\hline 3-hydroxyglutaric acid & 7.02 & 4.28 & 1.31 & 18.9 & 0.018 & 6.66 & 5.26 & 0.39 & 19.4 & 0.015 \\
\hline cis-pinonic acid & 6.82 & 6.05 & 0.41 & 21.8 & 0.029 & 4.49 & 4.16 & 0.21 & 16.8 & 0.018 \\
\hline norpinic acid & 0.87 & 0.51 & 0.15 & 1.76 & 0.003 & 0.74 & 0.50 & 0.07 & 1.99 & 0.003 \\
\hline pinic acid & 2.91 & 1.83 & 0.72 & 6.27 & 0.012 & 2.28 & 1.39 & 0.36 & 4.90 & 0.009 \\
\hline MBTCA $^{d}$ & 11.5 & 6.10 & 3.94 & 24.2 & 0.040 & 8.36 & 5.13 & 3.47 & 25.9 & 0.031 \\
\hline subtotal & 29.1 & 11.2 & 11.9 & 51.1 & 0.102 & 22.5 & 9.85 & 5.19 & 48.0 & \\
\hline $\mathrm{SOC}_{\text {monoterpenes }}\left(\mu \mathrm{gC} \mathrm{m}^{-3}\right)$ & 0.13 & 0.05 & 0.05 & 0.22 & 0.87 & 0.10 & 0.04 & 0.02 & 0.21 & 0.66 \\
\hline \multicolumn{11}{|c|}{ Tracer for $\beta$-caryophyllene SOA } \\
\hline$\beta$-caryophyllinic acid & 12.4 & 8.98 & 1.76 & 35.2 & 0.044 & 11.7 & 11.4 & 1.15 & 39.4 & 0.036 \\
\hline $\mathrm{SOC}_{\beta \text {-caryophyllene }}\left(\mu \mathrm{gC} \mathrm{m}^{-3}\right)$ & 0.54 & 0.39 & 0.08 & 1.53 & 2.91 & 0.51 & 0.50 & 0.05 & 1.71 & 2.37 \\
\hline total tracers & 244 & 129 & 62.9 & 542 & 0.75 & 260 & 194 & 21.8 & 834 & 0.76 \\
\hline total SOC $\left(\mu \mathrm{gC} \mathrm{m}^{-3}\right)$ & 1.76 & 0.87 & 0.46 & 3.45 & 11.2 & 1.85 & 1.30 & 0.12 & 4.89 & 11.0 \\
\hline
\end{tabular}

a std: standard deviation.

b $\mathrm{C}_{5}$-alkene triols: cis-2-methyl-1,3,4-trihydroxy-1-butene, trans-2-methyl-1,3,4-trihydroxy-1-butene, and 3-methyl2,3,4-trihydroxy-1-butene.

$c$ The total mass concentrations of SOC produced by isoprene (2-methylglyceric acid and 2-methyltetrols were used), monoterpenes, and $\beta$-caryophyllene were calculated using a tracer-based method reported by Kleindienst et al. (2007a).

${ }^{d}$ MBTCA: 3-methyl-1,2,3-butanetricarboxylic acid.

\section{Formation of secondary organic aerosol over Mt. Tai during MTX2006}

P. Q. Fu et al.

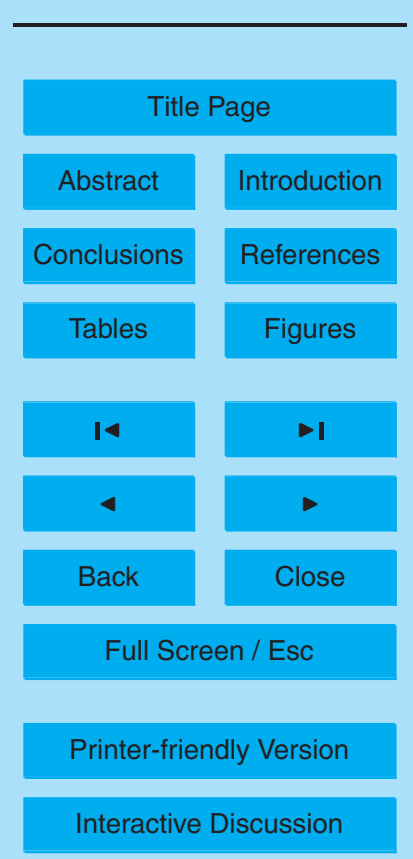


Table 2. Concentration ratios of total isoprene SOA tracers to monoterpene SOA tracers $\left(R_{\text {iso/mono }}\right)$ measured in the Mt. Tai aerosols compared to those reported in other studies.

\begin{tabular}{|c|c|c|c|c|c|c|c|}
\hline \multirow[b]{2}{*}{ Location } & \multirow[b]{2}{*}{ Type of aerosol } & \multicolumn{2}{|c|}{ Isoprene SOA tracers } & \multicolumn{2}{|c|}{ Monoterpene SOA tracers } & \multirow[b]{2}{*}{$R_{\text {iso/mono }}$} & \multirow[b]{2}{*}{ References } \\
\hline & & Tracers $^{a}$ & Aver. Conc. ${ }^{b}$ & Tracers $^{a}$ & Aver. Conc. & & \\
\hline Mt. Tai, China & TSP, nighttime & $1,2,3$ & 226 & $4,5,6,7,8$ & 22.5 & 10.0 & This study \\
\hline Mt. Tai, China & TSP, daytime & $1,2,3$ & 202 & $4,5,6,7,8$ & 29.1 & 6.94 & This study \\
\hline Hainan, China & $\mathrm{PM}_{2.5}, 24 \mathrm{~h}$ & $1,2,3$ & 51 & $5,7,8$ & 9.4 & 5.43 & (Wang et al., 2008) \\
\hline Changbai, China & $\mathrm{PM}_{2.5}$, daytime & $1,2,3$ & 140 & 7,8 & 38 & 3.68 & (Wang et al., 2008) \\
\hline Chennai, India & $\mathrm{PM}_{10}$, summer & $1,2,3$ & 34.3 & $4,5,6,7,8$ & 9.5 & 3.62 & (Fu et al., unpublished data) \\
\hline Sierra Nevada, USA & TSP & $1,2,3$ & 57 & $4,5,6$ & 18.3 & 3.10 & (Cahill et al., 2006) \\
\hline Changbai, China & $\mathrm{PM}_{2.5}$, nighttime & $1,2,3$ & 114 & 7,8 & 41 & 2.78 & (Wang et al., 2008) \\
\hline RTP, NC, USA & $\mathrm{PM}_{2.5}$ & 1,3 & 137 & $4,7,8,9,10,11,12$ & 154 & 0.89 & (Lewandowski et al., 2007) \\
\hline Rishiri Is., Japan & TSP & $1,2,3$ & 13.3 & $4,5,6,7,8$ & 15.7 & 0.85 & (Fu et al., unpublished data) \\
\hline Jülich, Germany & $\mathrm{PM}_{2.5}$ & $1,2,3$ & 20.5 & $4,5,7,8$ & 25.6 & 0.80 & (Kourtchev et al., 2008b) \\
\hline Hong Kong, China & $\mathrm{PM}_{2.5}$ & $1,2,3$ & 91.5 & $7,8,9,10,11,12$ & 199 & 0.46 & (Hu et al., 2008) \\
\hline Hyytiälä, Finland & $\mathrm{PM}_{1}$, daytime & $1,2,3$ & 22.4 & $4,5,7,8$ & 65 & 0.34 & (Kourtchev et al., 2008a) \\
\hline Hyytiälä, Finland & $\mathrm{PM}_{1}$, nighttime & $1,2,3$ & 15.6 & $4,5,7,8$ & 65 & 0.24 & (Kourtchev et al., 2008a) \\
\hline Alert, Canada & TSP, light spring & $1,2,3$ & 0.31 & $4,5,6,7,8$ & 1.3 & 0.24 & (Fu et al., 2009) \\
\hline Alert, Canada & TSP, dark winter & $1,2,3$ & 0.26 & $4,5,6,7,8$ & 3.2 & 0.08 & (Fu et al., 2009) \\
\hline
\end{tabular}

a Tracers: (1) 2-methyltetrols; (2) $\mathrm{C}_{5}$-alkene triols; (3) 2-methylglyceric acid; (4) pinic acid; (5) norpinic acid, (6) pinonic acid; (7) 3-hydroxyglutaric acid; (8) MBTCA; (9) 3-hydroxy-4,4-dimethylglutaric acid; (10) 3-isopropylpentanedioic acid; (11) 3-acetylpentanedioic acid; (12) 3-acetylhexanedioic acid.

${ }^{\mathrm{b}}$ averaged concentration in $\mathrm{ng} \mathrm{m}^{-3}$.

\section{Formation of secondary organic aerosol over Mt. Tai during MTX2006}

P. Q. Fu et al.

Title Page

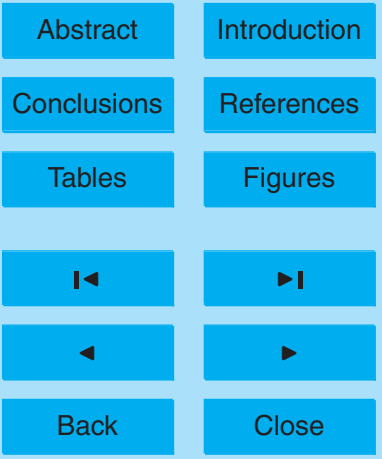

Full Screen / Esc

Printer-friendly Version

Interactive Discussion 


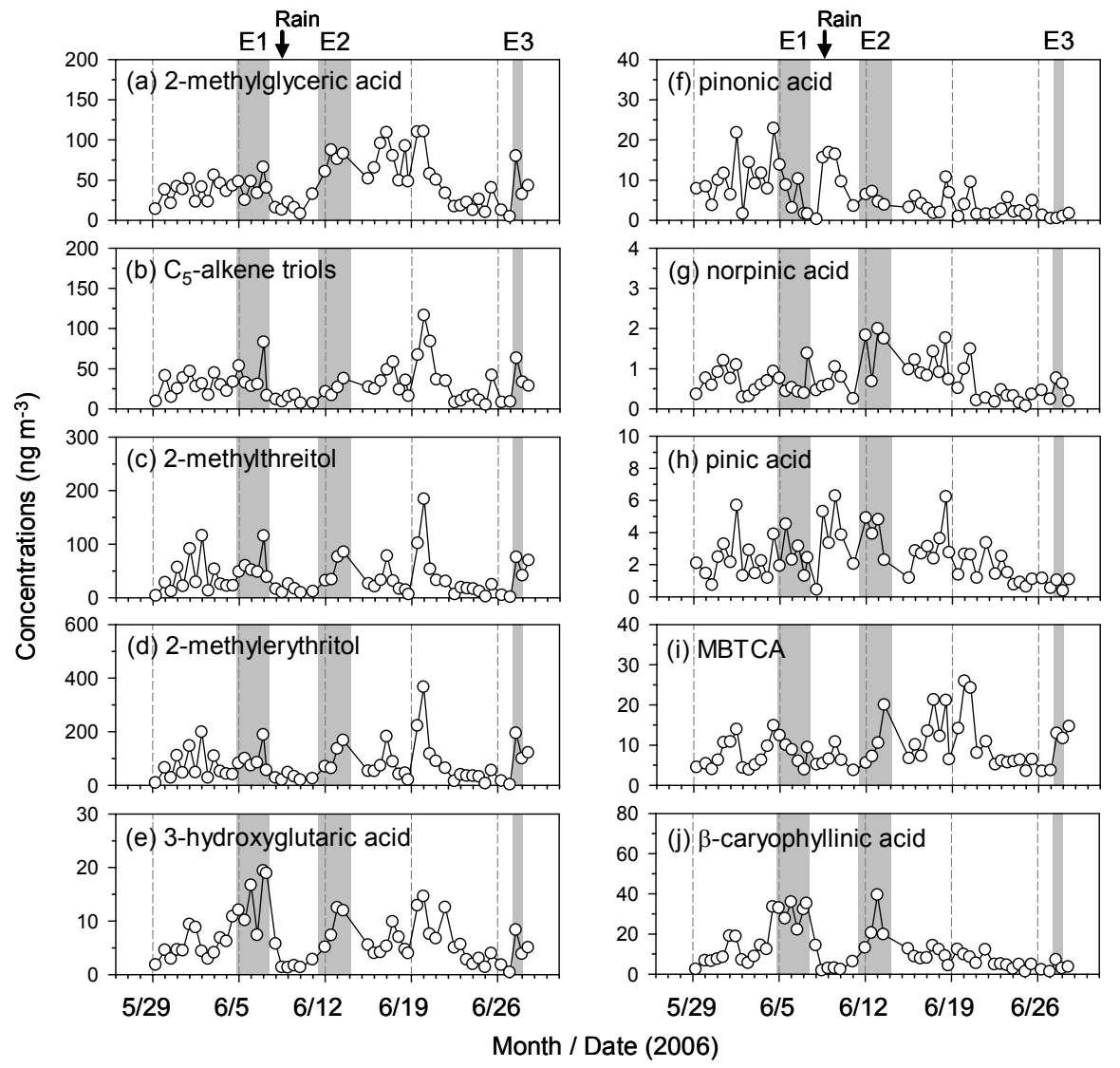

Fig. 1. Temporal variations of biogenic SOA tracers measured in the Mt. Tai aerosols during May-June, 2006. Event 1 (E1), E2, and E3 are significant biomass burning periods reported in a previous study (Fu et al., 2008).
ACPD

9, 16941-16972, 2009

\section{Formation of secondary organic aerosol over Mt. Tai during MTX2006}

P. Q. Fu et al.

Title Page

Abstract

Introduction

Conclusions

References

Tables

Figures

14

$\rightarrow$

$\triangleleft$

Back

Close

Full Screen / Esc

Printer-friendly Version

Interactive Discussion 


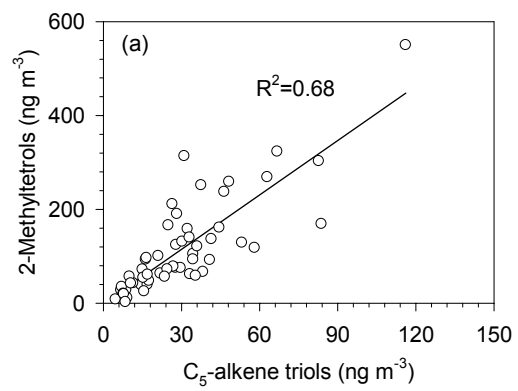

\section{ACPD}

9, 16941-16972, 2009

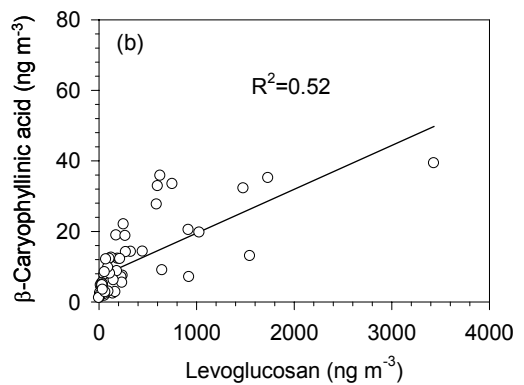

\section{Formation of secondary organic aerosol over Mt. Tai during MTX2006}

P. Q. Fu et al.

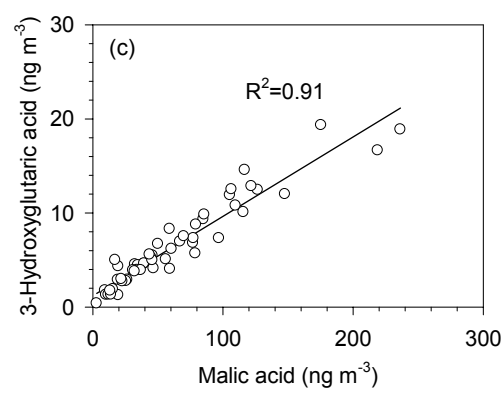

Title Page

Abstract

Conclusions
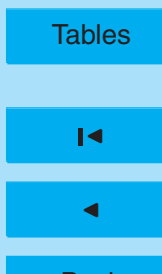

Back

\section{Introduction}

References

Figures

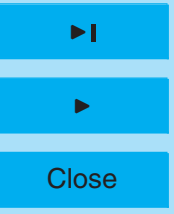

Full Screen / Esc

Printer-friendly Version

Fig. 2. Correlations between the concentrations of (a) $\mathrm{C}_{5}$-alkene triols and 2-methyltetrols, (b) levoglucosan and $\beta$-caryophyllinic acid, and (c) malic acid and 3-hydroxyglutaric acid. 


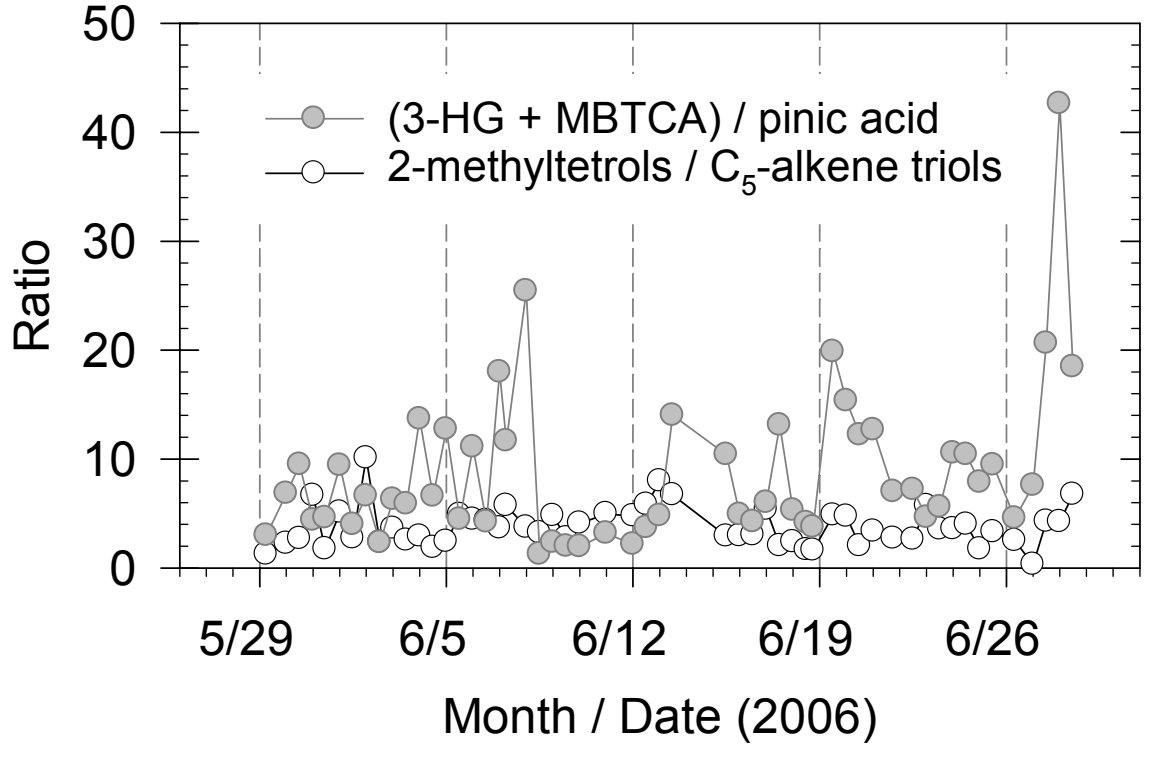

Fig. 3. Temporal trends of the concentration ratios of 2-metnyltetrols to $\mathrm{C}_{5}$-alkene triols (white circle), and sum of 3-hydroxyglutaric acid (3-HG) and 3-methyl-1,2,3-butanetricarboxylic acid (MBTCA) to pinic acid (grey circle).

\section{Formation of secondary organic aerosol over Mt. Tai during MTX2006}

P. Q. Fu et al.

Title Page

Abstract

Introduction

Conclusions

References

Tables

Figures

14

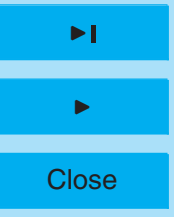

Back

Full Screen / Esc

Printer-friendly Version

Interactive Discussion 
(a) daytime

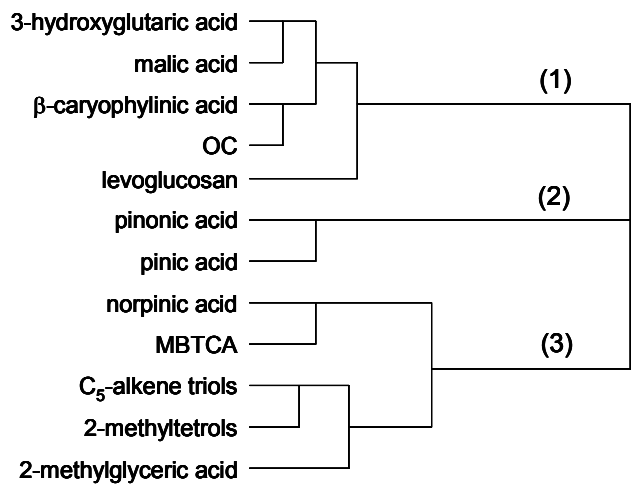

(b) nighttime

3-hydroxyglutaric acid

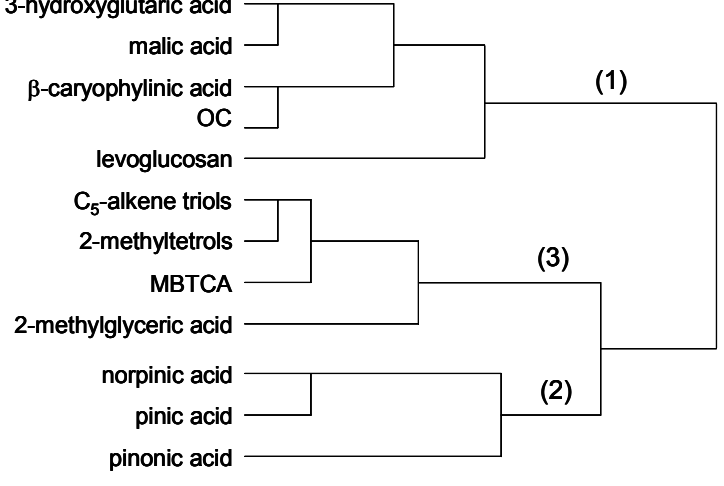

Fig. 4. Hierarchical cluster analysis of biogenic SOA tracers, levoglucosan, malic acid and organic carbon $(\mathrm{OC})$ in the Mt. Tai aerosols during (a) daytime, and (b) nighttime.

\section{ACPD}

9, 16941-16972, 2009

\section{Formation of secondary organic aerosol over Mt. Tai during MTX2006}
P. Q. Fu et al.

\section{Title Page}

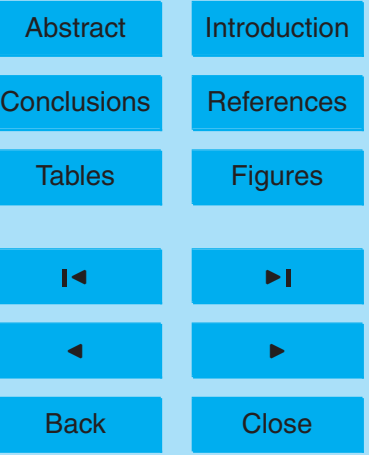

Full Screen / Esc

Printer-friendly Version

Interactive Discussion 


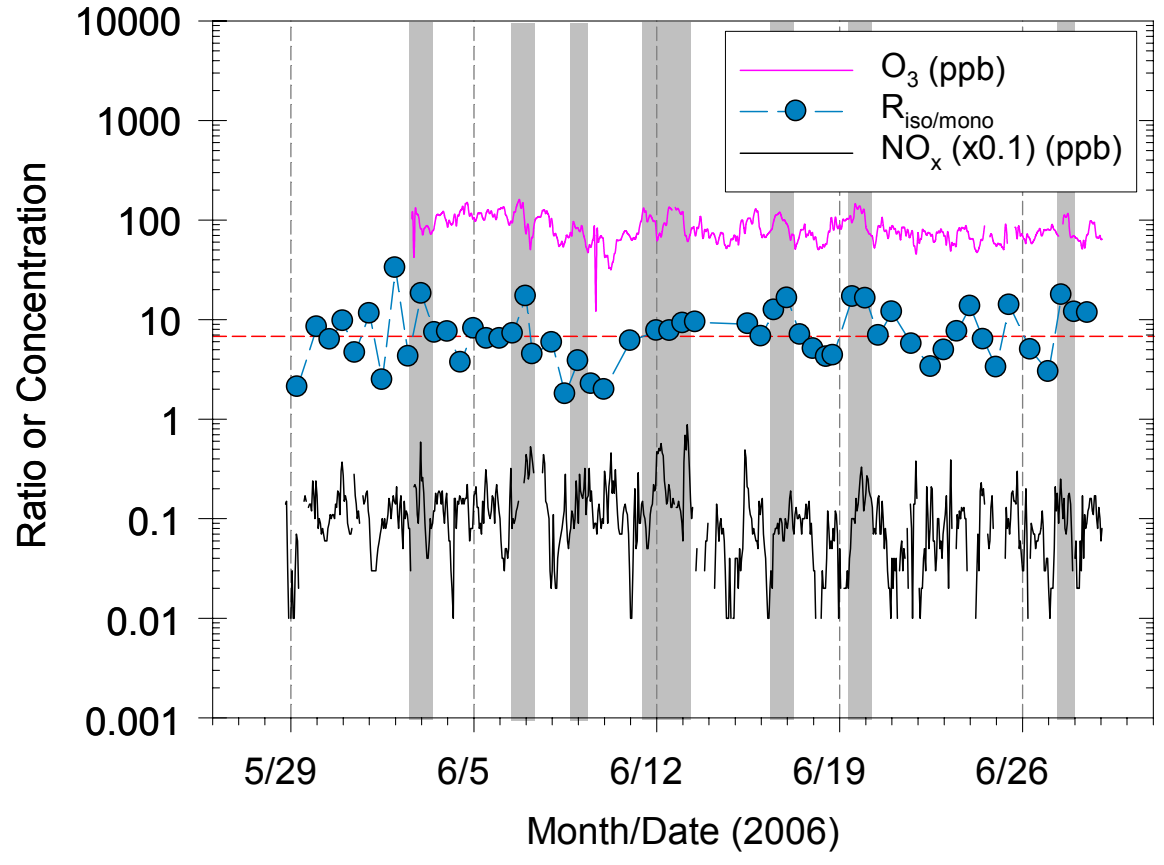

Fig. 5. Time series for the ratio of isoprene to monoterpenes oxidation products $\left(R_{\text {iso/mono }}\right)$, and the observed concentrations of $\mathrm{O}_{3}$ and $\mathrm{NO}_{\mathrm{x}}$ in the troposphere over Mt. Tai during MTX2006. The dashed red line represents the median value of $R_{\text {iso } / \text { mono }}=6.93$.

\section{Formation of secondary organic aerosol over Mt. Tai during MTX2006}

P. Q. Fu et al.

\section{Title Page}

Abstract

Conclusions

Tables

14

4

Back
Introduction

References

Figures

$\rightarrow$

$>$

Close

\section{Full Screen / Esc}

Printer-friendly Version

Interactive Discussion 


\section{ACPD}

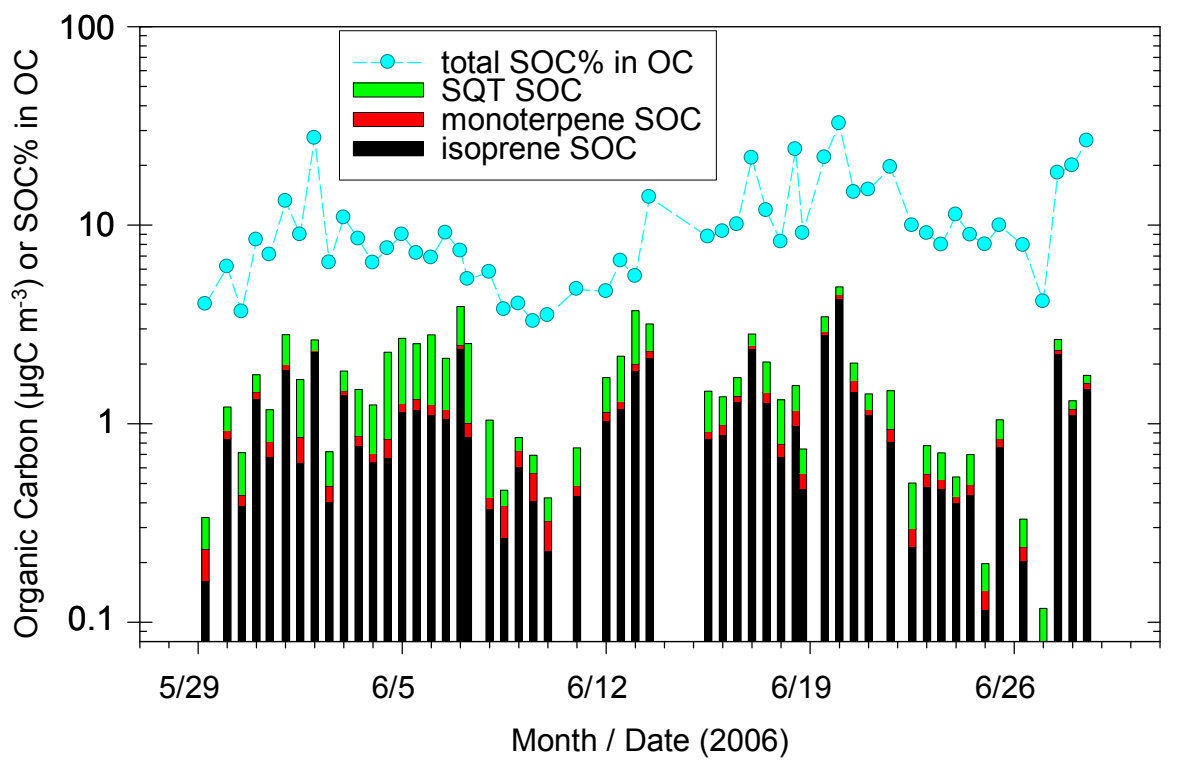

Fig. 6. Estimated contributions of different biogenic VOCs to SOC, and the temporal variations of the percentage of total SOC in OC.

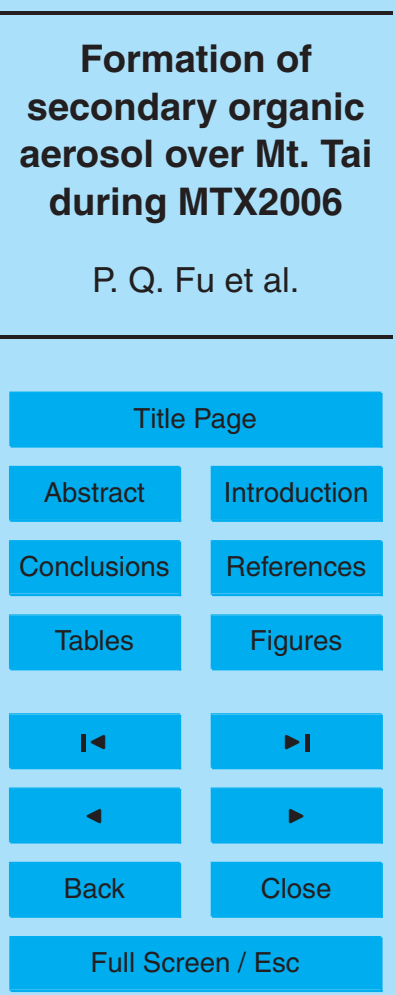

Printer-friendly Version

Interactive Discussion 